\title{
NBSIR 78-1495
}

\section{Factors Affecting the Durability of Adobe Structures}

Paul Wencil Brown'

Carl R. Robbins ${ }^{2}$

James R. Clifton'

\author{
${ }^{1}$ Center for Building Technology \\ National Engineering Laboratory \\ National Bureau of Standards \\ Washington, D.C. 20234
}

${ }^{2}$ Center for Materials Research National Measurement Laboratory National Bureau of Standards Washington, D.C. 20234

July 1978

'repared for 


\section{FACTORS AFFECTING THE DURABILITY OF ADOBE STRUCTURES}

Paul Wencil Brown ${ }^{1}$

Carl R. Robbins ${ }^{2}$

James R. Clifton ${ }^{1}$

'Center for Building Technology National Engineering Laboratory National Bureau of Standards Washington, D.C. 20234

${ }^{2}$ Center for Materials Research National Measurement Laboratory National Bureau of Standards Washington, D.C. 20234

July 1978

Prepared for National Park Service

Washington, D.C. 20240

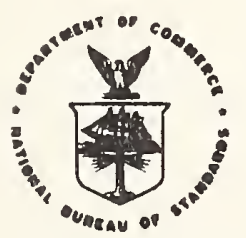

U.S. DEPARTMENT OF COMMERCE, Juanita M. Kreps, Socrotary Dr. Sidney Harman, Under Socrotary

Jordan J. Baruch. Assistant Socretery for Science and Technology NATIONAL BUREAU OF STANDARDS, Emest Amblor, Diroctor 



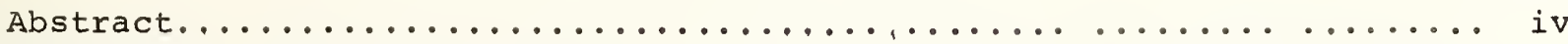

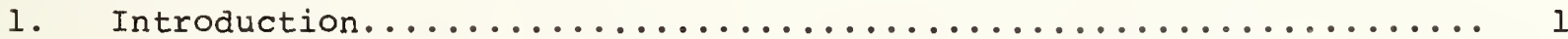

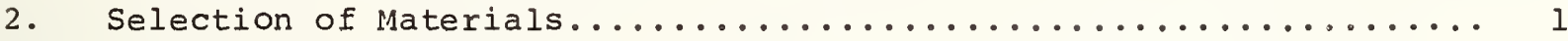

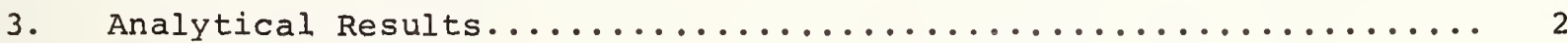

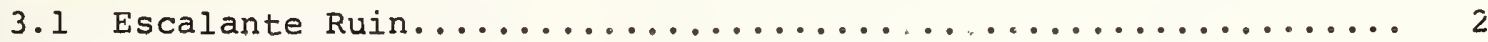

3.1.1 General Observations and Visual Analysis............ 2

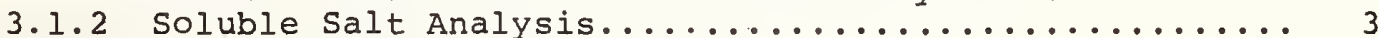

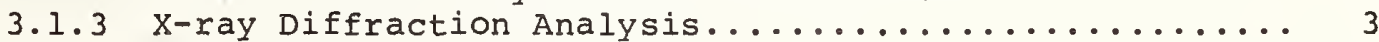

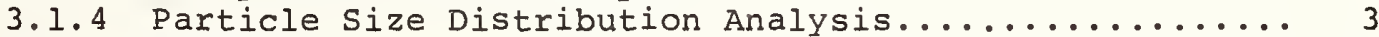

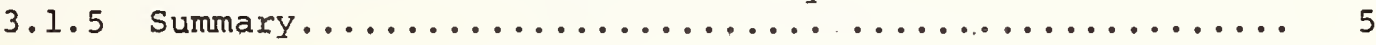

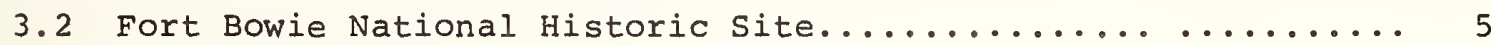

3.2.1 General Observations and Visual Analysis........... 5

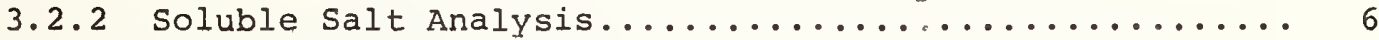

3.2.3 X-ray Diffraction and Particle Size Distribution

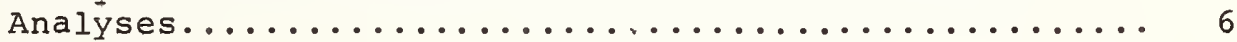

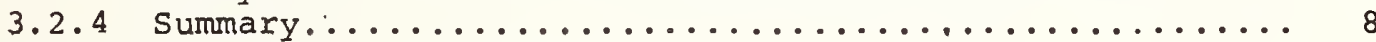

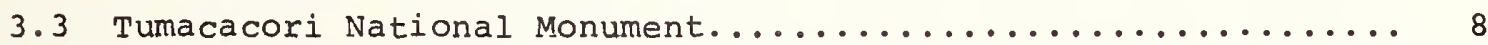

3.3.1 General Observations and Visual Analysis........... 8

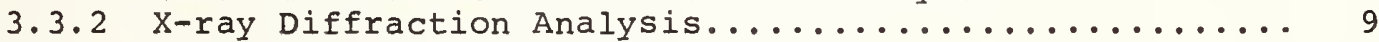

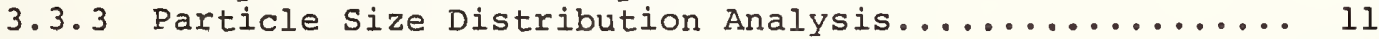

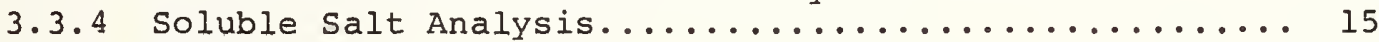

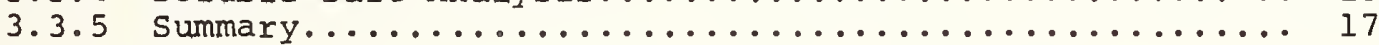

4. Porosity Analyses of Tumacacori, Fort Bowie, and Escalante....... 17

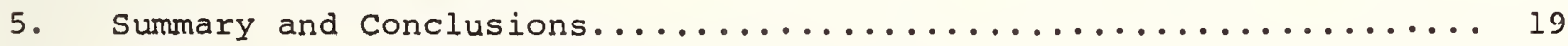

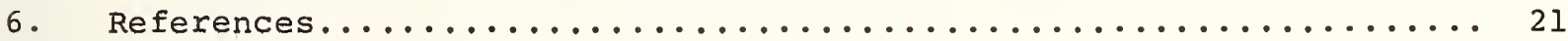

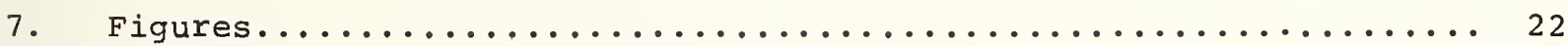

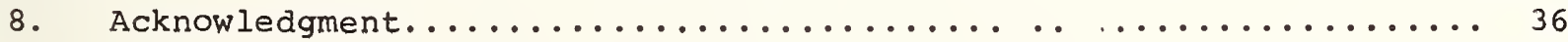




\section{ABSTRACT}

Adobe samples from three structures of historic interest in the state of Arizona were analyzed to determine their mineral assemblages, particle size distributions, soluble salt contents, and porosities. These analyses were accompanied by microscopic observations of polished sections and thin sections. These data were correlated with the weathering observed and it was found that soluble salt action was primarily responsible for the deterioration of the adobe from one of the sites The nature of the particle size distribution has contributed to the rapid deterioration of the adobe from a second site. The adobe from a third site was found to be well consolidated due to the presence of large amounts of calcite. 
FACTORS AFFECTING THE DURABILITY OF ADOBE STRUCTURES

by

Paul Wencil Brown

Carl R. Robbins

James R. Clifton

1. INTRODUCTION

A large number of adobe and rammed earth structures have been built in the southwestern United States over a period of approximately 10 centuries. Due to the scarcity of more conventional building materials and the climatic conditions prevalent in the region, adobe was the primary material of construction employed. Adobe is a mixture of sand, silt, and clay, however, straw is usually added and gravel is usually present. Sand may also be added to an adobe soil to achieve the desired proportions [1] 1!. When mixed with water, adobe can be cast into brick or block, cast in-place, or used as mortar. Adobe exhibits excellent stability in climates of extreme dryness as is evidenced by the antiquity of Middle Eastern adobe structures such as the Ziggurat of Agar Quf. However, exposure of an adobe structure to moisture, whether from rain, rising ground water or high humidity, causes deterioration generally called weathering. The rate at which adobe weathers is affected by its mineralogical composition, particle size distribution, porosity distribution and soluble salt content as well as its moisture content. Major weathering processes include erosion or leaching of the silt-clay matrix, soluble salt action, dimensional instability associated with cyclic wetting and drying, and freezethaw damage [1].

It is the purpose of this paper to examine the factors which affect the weathering of adobe.

\section{SELECTION OF MATERIALS}

Adobe material was obtained from three sites in the state of Arizona. These sites are Tumacacori National Monument, Fort Bowie National Historic Site, and Escalante Ruin. Tumacacori National Monument is a mission church, San José de Tumacacori, and other buildings constructed by Franciscan priests in the late 18th century. The church was abandoned in 1848 and fell into disrepair until 1921. Since then, repair work has been essentially limited to preserving the existing structure. Fort Bowie was a cavalry fort first constructed in 1866. A second fort was built in 1868 and was in use for the next 16 years and then abandoned. Escalante Ruin is the remains of a prehistoric farming community built along the Gila River. This site was occupied for several centuries and many of the artifacts excavated date from A.D. 1150-1450; however, portions of the site date as early as A.D. 900 .

Ifumbers in brackets refer to references at the end of this report. 
The samples of adobe taken from Tumacacori ranged from well consolidated to severely deteriorated. A sample of soil from the site was also obtained. Three samples were taken from various locations along an interior wall of the nave of the church and showed varying degrees of deterioration. One sample, considered to be representative of unweathered adobe, was taken from an interior wall of the sanctuary. In addition other samples were taken from the top of an exposed wall, and from the exterior wall of the nave. The sample of adobe from Fort Bowie was taken from a severely deteriorated corral wall. The sample from the Escalante Ruin was taken from the wall of a dwelling unit and was well consolidated. The appearance of a typical polished section of each adobe included in this investigation is shown in Figure 1.

\section{ANALYTICAL RESULTS}

3.1 Escalante Ruin

3.1.1 General Observations and Visual Analysis

Escalanate adobe is well consolidated, pinkish gray in color (Munsell soil chart notation 7.5 yr 7/2) [2] and appears to contain a high percentage of fine fraction relative to coarse aggregate. The latter consists primarily of angular to subrounded quartz grains and rounded residual fragments of highly weathered igneous rock (granites) in which the feldspar has been altered to clays. The light color of the specimen suggested the presence of a carbonate which was confirmed by reaction with dilute hydrochloric acid. The carbonate, found to be calcite, is present in considerable concentration and is distributed throughout the sample.

This adobe is predominantly fine grained and dense, with an even distribution of relatively large pores (1-2 mm diameter). Subsamples of a larger Escalante specimen showed considerable variation in their resistance to the destructive effects of water. Although $275 \%$ of these subsamples were quite resistant, the remainder dissociated readily when immersed in water, reflecting a significant variation within a relatively small sample volume.

Examination of an epoxy impregnated polished section of this adobe in reflected white light shows an aggregate fraction $\sim 5 \mathrm{~mm}$ in its largest dimension (Figure 2). This size fraction consists mainly of rounded to subangular clear and milky quartz grains, and grains of feldspars. In the finer fractions the angularity of the aggregate rapidly increases with decreasing aggregate size. In addition to quartz and feldspars, amphihole, chlorite, and titanite are observed. The calcium carbonate occurs as a finely crystalline white material deposited between the finer grains, as a filling in the smaller pores, and as a lining of the larger pores. It is both a cementing agent and a pigment, whose presence results in a light colored adobe. 
A petrographic thin section, prepared after impregnating the adobe with epoxy, was examined in polarized light[2]. The outstanding feature of the material is its microcrystalline calcite-clay matrix which surrounds the larger grains and serves as the cementing agent of the adobe (Figure 3 ). A variety of quartz grains are present. These range from small angular individual fragments to large aggregate material which is frequently strained, polycrystalline and rounded in habit. Both alkaline (microcline, orthoclase) and calcic feldspars are abundant. Much of the feldspar is chemically unaltered. but some of the plagioclase has been extensively weathered to clay. In addition, amphibole, chlorite and the iron oxides hematite and magnetite are present in minor amounts.

3.1.2 Soluble Salt Analysis

Qualitative elemental analysis of the soluble salt fraction was obtained with a scanning electron microscope (SEM) equipped with an energy dispersive $x-r a y$ analysis (EDXA) attachment. The soluble salt fraction was obtained by dispersing the adobe in distilled water, filtering the liquid, evaporating it to dryness and collecting the salt as the residue[2]. The elements identified by this method in apparent order of abundance are: $\mathrm{Ca}, \mathrm{Cl}, \mathrm{S}, \mathrm{Si}$, and trace amounts of $\mathrm{Mg}, \mathrm{K}$, and Al. The energy distribution spectrum of this fraction obtained by EDXA is shown in Figure 4. This spectrum typifies the EDXA data obtained in the analyses of soluble salts present in other samples.

\subsubsection{X-ray Diffraction Analysis}

A 100 gram subsample of the Escalante specimen was analyzed using $x$-ray diffractometry in order to obtain an estimate of the relative abundance of the various minerals present in the bulk sample[2]. The following minerals, listed in apparent order of abundance, were identified as calcite, quartz, microcline, plagioclase, orthoclase and illite.

\subsubsection{Particle Size Distribution Analysis}

The particle size distribution in a 260 gram sample was determined using sieving and sedimentation techniques[2]. The soluble salt content determination was carried out on a companion sample. These data along with x-ray diffraction analysis data for the various size fractions are reported in Table 1. The minerals described in this table are listed in decreasing order of abundance. Quartz, feldspars, calcite, and mica are the major components of the gravel and sand fractions while the major components of the silt and clay size fractions are calcite, illite, and quartz. Calcite, because of its insolubility and cementing properties, is not sensitive to the usual dispersion techniques and as a consequence, was observed in virtually all size fractions.

The coarse fractions (4-50 mesh) of the adobe specimen from Escalante Ruin consist primarily of a complex of igneous mineral and rock fragments 
Table 1. Summary of Analysis of

Escalante Adobe

\begin{tabular}{|c|c|c|c|c|}
\hline $\begin{array}{c}\text { Size Fi } \\
\text { Mesh P } \\
\text { (U.S. }\end{array}$ & $\begin{array}{l}\text { raction } \\
\text { er Ince } \\
\text { Standard) }\end{array}$ & $\begin{array}{c}\text { Percent } \\
\text { of Sample } \\
\text { Weight }\end{array}$ & $\mathrm{X}$-ray Analysis & Remarks \\
\hline Grave1. & +4 & 4.35 & - & $\begin{array}{l}\text { Subangular to rounded } \\
\text { grains of quartz, very } \\
\text { altered granite, 2- } \\
\text { feldspar biotite gran- } \\
\text { ite (little altered), } \\
\text { quartzite, schist }\end{array}$ \\
\hline-4 & +8 & 4.93 & & 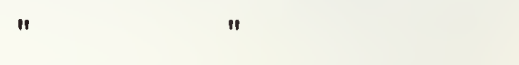 \\
\hline$\frac{\text { Sand: }}{-8}$ & +16 & 4.62 & - & 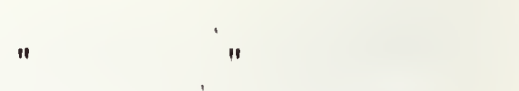 \\
\hline-16 & +30 & 4.59 & $\begin{array}{l}\text { Quartz, feldspars, } \\
\text { calcite, mica }\end{array}$ & $\begin{array}{l}\text { Flakes of chemically } \\
\text { altered biotite mica } \\
\text { observed }\end{array}$ \\
\hline-30 & +50 & 6.21 & $"$ & . \\
\hline+50 & +100 & 10.00 & $\begin{array}{l}\text { Quartz, feldspars, } \\
\text { calcite, mica (trace) }\end{array}$ & $\begin{array}{l}\text { Quartz and feldspars are } \\
\text { the major minerals }\end{array}$ \\
\hline-100 & +200 & 11.55 & $\begin{array}{l}\text { Quartz, feldspars, } \\
\text { cạlcite, mica }\end{array}$ & " \\
\hline-200 & +270 & 11.28 & $"$ & " " \\
\hline-270 & +400 & 6.38 & $\begin{array}{l}\text { Quartz, calcite, } \\
\text { feldspars, trace of } \\
\text { illite clay-mica }\end{array}$ & $\begin{array}{l}\text { Quartz is the major } \\
\text { mineral and most } \\
\text { angular of the group }\end{array}$ \\
\hline-400 & $+20 \mu \mathrm{m}$ & 13.18 & $\begin{array}{l}\text { Quartz, calcite, feld- } \\
\text { spars, illite clay- } \\
\text { mica }\end{array}$ & $\begin{array}{l}\text { Quartz and calcite are } \\
\text { the major minerals }\end{array}$ \\
\hline $\begin{array}{l}\text { Silt } \\
(-20 \mu \mathrm{m}\end{array}$ & $+2 \mu \mathrm{m})$ & 15.37 & $\begin{array}{l}\text { Calcite, mixed layer } \\
\text { clay minerals, pre- } \\
\text { dominantly illite, } \\
\text { quartz, feldspars }\end{array}$ & $\begin{array}{l}\text { Calcite/illite ratio } \\
\text { much higher than in } \\
\text { clay fraction }\end{array}$ \\
\hline $\begin{array}{l}\text { Clay } \\
(<2 \mu \mathrm{m})\end{array}$ & & 6.08 & $\begin{array}{l}\text { Calcite, mixed layer } \\
\text { clay minerals, pre- } \\
\text { dominately illite, } \\
\text { quartz }\end{array}$ & $\begin{array}{l}\text { Calcite is the major } \\
\text { mineral }\end{array}$ \\
\hline Organi & & $\mathrm{Nil}$ & & \\
\hline $\begin{array}{l}\text { Solubl } \\
\text { Salts }\end{array}$ & & 1.6 & & $\begin{array}{l}\text { Primarily calcium } \\
\text { chloride and gypsum }\end{array}$ \\
\hline
\end{tabular}


(granites). The norphology of the grains in this fraction ranges fror angular to roundec. Quartz is prominent and occurs as rose, milky or colorless grains. Tncivirual fragments of chemically unaltered feldspar crystals are present As are angular fragments of a granite. Grains of a second type of granite are rounded and its feldspars are highly weathered to clays. Occasional rounded grains of quartzite and schist are observed along with grains of calcite. Minor ninerals present are an amphibole, chlorite, weathered biotite nica, and titanite. Below 50 mesh, the rock fragments become less prominent and from -50 to +270 mesh, the nineral asserblage, in order of decreasing abunciance, consists of guartz, felclspars, microcrystalline calcite grains and mica. From -270 mesh to $+2 \mu \mathrm{m}$, calcite replaces the feldspars as the second most abundant mineral and small amounts of illite clay-mica appear in the x-ray diffractograns. Calcite is the major mineral in the silt fraction and is present mainly in microcrystalline form. A mixed layer, predominantly illitic, clay is present along with quartz and feldspars. In this size fraction, only the quartz grains are angular. The minerals observed in the clay size fraction are calcite, which is a major component, a moderate amount of a mixed layer clay showing a broad (001) x-ray diffraction peak at $\sim 10.8 \AA$, and a small amount of quartz. The clay present is predominantly illite which is a dimensionally stable clay.

The clay-silt matrix is the boncing or cementing material of adobes. The clay which is slowly. formed by chemical weathering, and which is present on the surfaces of all size fractions of feldspars also contrijutes to bonding. This is particularly true in the clay-silt size fraction which is composer of clay particles initially present plus those on the surfaces of the tiny grains of feldspars that are gradually being converter to clays.

\section{1 .5 summary}

The calcite-clay bonding matrix of Escalante arobe is its distinctive feature. The calcite-clay ratio is not uniform in the ratrix, but ranges on a micro scale from regions rich in clay to those which are nearly pure calcite. The latter are very resistant to the eroding effects of water and account for the variability in slaking resistance observed. The presence of calcite accounts for both the color and the high degree of consolidation generally observed in this aclobe.

\subsection{Fort Bowie National Historic Site}

3.2. I General Observations and Visual Analysis

The specimen of adotse from an exterior corral wall of Fort Bowie Jational fionument analyzed is yellowish brown (10 yr. 5/4, Nunsell soil cirart notation) and highly porous with many fine pores and a high percentage of large ones ranging from $\sim 1 \mathrm{~mm}$ to $3 \mathrm{~mm}$ in diameter. sicrostructural details of the adobe are obscured by a clay-silt coating of the grains. Gross structural details which may be observed are fragments of resicual organic material such as grass or straw and a high percentage of coarse aggregate. 
A distinctive feature of the Fort Bowie adobe observed in polished section is the high ratio of aggregate to fine matrix. The aggregate consists primarily of angular to subrounded grains of quartz and feldspars ranging from $\sim 0.3 \mathrm{~mm}$ to $\sim 15 \mathrm{~mm}$ in largest dimension. The general aspect of the material is shown in Figure 5.

Examination of a petrographic thin section in polarized light showed large mosaic quartz grains. Large feldspar grains including microcline and orthoclase, both unaltered and altered to clays, and plagioclase grains, both unaltered and altered to clays, were also observed. The grains were angular to subrounded in habit and this assemblage persisted over a wide size range. In addition to the major mineral assemblage, minor amounts of micas, amphibole, and hematite were observed. The dominant feature observed in thin section is the high ratio of relatively coarse grains to clay-silt matrix, Figure 6 . The high proportion of large grains seperated and bonded by many narrow regions of silt-clay matrix is readily observed in this figure.

\subsubsection{Soluble Salt Analysis}

Only a small amount of soluble salts was found in this sample. Energy dispersive $x$-ray analysis was used to obtain a qualitative estimate of the elements present in the soluble salt fraction. Elements identified by this method, in apparent order of abundance, are: $\mathrm{Ca}, \mathrm{Si}, \mathrm{K}, \mathrm{S}, \mathrm{Cl}$, and $\mathrm{Mg}$.

\subsubsection{X-ray Diffraction and Particle Size Distribution Analyses}

A subsample of the Fort Bowie specimen was crushed, ground and thoroughly mixed for x-ray analysis of the bulk sample. The following minerals (Listed in apparent order of abundance) were identified: quartz, plagioclase, microcline, orthoclase, weathered muscovite, illite, magnetite and a trace of kaolinite. Table 2 lists the particle size distribution, soluble salt and mineralogical data for this adobe. The minerals are listed in decreasing order of abundance. Size distribution analyses revealed a high proportion of coarse aggregate. Over $25 \%$ of this material is gravel and nearly $60 \%$ is larger than 50 mesh.

The adobe from the Fort Bowie National Historic Site is composed primarily of fragments of igneous rocks and minerals bonded by a clay-silt matrix. The coarse aggregate (10-15m in its longest dimension) is angular and consists mainly of granite fragments with weathered feldspars, quartz grains and occasional fragments of quartzite. Amphibole and magnetite are present in minor amounts.

With decreasing grain size the rock fragments are replaced by quartz and feldspars, and the assemblage of quartz, feldspars, and mica and magnetite persists through several size fractions to $\sim 20 \mu \mathrm{m}$. At this point, illite and Kaolinite are detected by x-ray analysis. The proportion of these minerals increases with decreasing grain size as the clay size ( $<2$ microns) is approached. The clay fraction in decreasing order of abundance consists of illite-mica, quartz, and kaolinite and is dimensionally stable. 
Table 2. Summary of Analysis of

Fort Bowie Adobe

\begin{tabular}{|c|c|c|c|c|}
\hline $\begin{array}{l}\text { Size Fri } \\
\text { Mesh Per } \\
\text { (U.S. S }\end{array}$ & $\begin{array}{l}\text { action } \\
\text { Inch } \\
\text { tandard) }\end{array}$ & $\begin{array}{l}\text { Percent } \\
\text { of Sample } \\
\text { Weight }\end{array}$ & $\mathrm{x}$-ray Analysis & Remarks \\
\hline Gravel: & & & & \\
\hline & +4 & 13.39 & & $\begin{array}{l}\text { Large angular grains of } \\
\text { igneous rocks (two feld- } \\
\text { spar granites). Some of } \\
\text { the feldspars are highly } \\
\text { altered to clays. Amphi- } \\
\text { bole and magnetite present }\end{array}$ \\
\hline-4 & +8 & 12.12 & & $"$ \\
\hline$\frac{\text { Sand: }}{-8}$ & +16 & 11.99 & & $"$ \\
\hline-16 & +30 & 11.06 & $\begin{array}{l}\text { Quartz, feldspars, } \\
\text { magnetite, mica } \\
\text { (trace) }\end{array}$ & $\begin{array}{l}\text { As above with individual } \\
\text { quartz grains more abun- } \\
\text { dant }\end{array}$ \\
\hline-30 & +50 & 9.50 & $\begin{array}{l}\text { Quartz, feldspar, } \\
\text { mica, magnetite }\end{array}$ & $\begin{array}{l}\text { As above with individual } \\
\text { quartz and feldspar grains } \\
\text { more abundant }\end{array}$ \\
\hline-40 & +100 & 7.08 & $"$ & $\begin{array}{l}\text { Rock fragments decreasing. } \\
\text { Quartz and feldspar grains } \\
\text { predominant }\end{array}$ \\
\hline-100 & +200 & 6.47 & $"$ & $\begin{array}{l}\text { Quartz and feldspar are the } \\
\text { major minerals }\end{array}$ \\
\hline-200 & +270 & 3.20 & $"$ & $"$ \\
\hline-270 & +400 & 2.11 & $"$ & $\begin{array}{l}\text { "Feldspar grains are angular } \\
\text { to subrounded and show some } \\
\text { degree of alteration to } \\
\text { clays. Quartz grains are } \\
\text { more angular }\end{array}$ \\
\hline-400 & $+20 \mu \mathrm{m}$ & 7.63 & $\begin{array}{l}\text { Quartz, feldspars, } \\
\text { illite-mica, kaolinite } \\
\text { (trace), magnetite } \\
\text { (trace) }\end{array}$ & \\
\hline $\begin{array}{l}\text { Silt } \\
(-20 \mu \mathrm{m}\end{array}$ & $+2 \mu \mathrm{m})$ & 8.86 & $\begin{array}{l}\text { Quartz, illite-mica } \\
\text { feldspars, kaolinite }\end{array}$ & \\
\hline $\begin{array}{l}\text { Clay } \\
(-2 \mu \mathrm{m})\end{array}$ & & 6.56 & $\begin{array}{l}\text { Illite-mica, quartz, } \\
\text { kaolinite }\end{array}$ & \\
\hline Organic & & $\mathrm{Nil}$ & & \\
\hline $\begin{array}{l}\text { Soluble } \\
\text { Salts }\end{array}$ & & 0.03 & & \\
\hline
\end{tabular}




\subsection{Surmary}

The large number of pores with diameters in the range of $\sim 1$ to 3rum (Figure 1) and the high ratio of coarse aggregate to bonding natrix (Figure 6 and Table 2) are distinctive features of the adobe from the corrals at Fort Bowie. These factors account for the severe ieterioration of this structure over a relatively short time span. The high degree of porosity allows the intrusion of water which reduces the shear resistance of the silt-clay matrix to the point where it cannot resist the flow of the coarse aggregate which is present in high proportion.

\subsection{Tumacacori National Monument}

The locations of the adobe samples taken from Tumacacori National ronument, their identification codes, and their condition when sampled are inclicated in Figure 7. An additional sample, Tols, is a soil sample taken from the H.F. corner of the grounds. Three of these specimens To 18 (interior), To ${ }_{10}$ (exterior) and $T_{15}$ (soil) were size fractionated and the size fractions were studied in detail. The remaining four samples were selected to investigate other aspects of this adobe.

\subsubsection{General Observations and Visual Analysis}

A typical specimen of Tumacacori adobe is dark brown (Munsell notation $7.5 \mathrm{yr} \mathrm{4/2).} \mathrm{As} \mathrm{in} \mathrm{the} \mathrm{case} \mathrm{of} \mathrm{the} \mathrm{other} \mathrm{adobes} \mathrm{investigated,} \mathrm{most} \mathrm{of} \mathrm{the} \mathrm{struc-}$ tural detail is obscured by the fine matrix which coats the larger grains. This adobe has many fine pores. It also contains coarse pores ranging up to $4 \mathrm{~mm}$ in diameter. Resiciual fragments of organic material (straw, grass or twigs) are preserved in the finer fraction of the acobe. This adobe is in general wellconsolidated and contains a much lower proportion of coarse aggregate than the adolve from Fort Bowie. Occasional rounded to subrounded grains of quartz and granites are observec but most of the aggregate is not visible. Small wilite pore fillings of gypsum are present in several of the specinens. Calcite is. also present.

Epoxy-impregnated polished sections of specimens To 10 ' To 11 , To 12 ' To $16^{\prime}$ and $\mathrm{TO}_{18}$ were prepared for examination in reflectec white light at low magnification. The reneral aspect of the material is sion in Figure 5 . The large aggregate consists mainly of grains of quartz and chemically weathered granites. The angularity of the aggregate grains increases rapidly with decreasing grain size in the finer size fractions. The white material visible in many of the pores is gypsum.

Although gypsum was observed in all specimens, it was most abuniant in speciment $\mathrm{Do}_{11}$ which was taken from a wet area of the structure where ground vater is active. Fuhedral crystals of gypsum up to $3 \mathrm{~mm}$ in their longest dimension were observed in a polished specimen of $\mathrm{To}_{11}$. 
These crystals were commonly interconnected by small gypsum fillec? veins or channels. The general aspect of the adobe from this sampling site may be seen in a photomicrograpil of an unpolished surface, Figure 9. Examination of a petrographic thin section $\left(\mathrm{TO}_{17}\right)$, which is typical of Tumacacori adobe, shows a fabric and mineral assemblage quite different from those of Escalante and Fort Bowie, and distinctive for this material. The coarse aggregate consists of Loth rounded and angular grains of quartz, rounded fragments of quartzite, euhedral crystals of unaltered alkaline feldspar, and angular to rounded grains of calcic feldspars, most showing chemical alteration to clay. In addition chlorite, hematite, muscovite, altered amphibole, gypsum and ittanite are present in a clay-sil matrix. A distinctive feature of this adobe is the chemical zoning of the felcispars ohich is easily observed in polarized light, Figure 10.

3.3.2 x-ray Diffraction Analysis

Bulk $x$-ray powder diffraction patterns were taken of samples To $10^{\prime}$ To $11^{\prime}$ To ${ }_{12}$, To 15 and $\mathrm{TO}_{17}{ }^{\circ}$ All patterns were quite similar, differing mainly in the relative proportions of the various minerals present. These differences, however, are not large and can probably be attributed to the proportioning of the adobe soil with sand during the construction of this structure. The nature of this proportioning is indicated by comparison of the particle distribution of the soil sample, To 15 with those of samples $\mathrm{TO}_{10} \mathrm{\prime}^{\prime}$ and $\mathrm{TO}_{18}$ which were taken from the structure. The percentage weight of the silt-clay fractions in the soil sample is 83.3 while those of $\mathrm{TO}_{10}$ and $\mathrm{TO}_{18}$ are 23.9 and 18.1 , respectively. This indicates that the soil to sand ratio used in proportioning adobe for Tumacacori was about 1 to 4 . In addition the rounded aspect and the general absence of particle angularity of the grains in the coarser sand and gravel fractions of Tumacacori adobe indicates that the sand was subjected to abrasive action. Particles of this size tend to become rounded through the action of running water. This suggests that this material was obtained from a stream near the site.

The diffraction pattern of $\mathrm{TO}_{12}$ shows the following minerals, listed in apparent order of abundance: quartz, alkaline and calcic feldspars, muscovite, amphibole, biotite, illite, and traces of kaolinite and gypsum. Sample To 10 is very similar to $\mathrm{TO}_{12}$ but contains more gypsum, sample To 17 contains less muscovite, alkali feldspar, and amphibole, and sample To ${ }_{11}$ contains more alkali feldspar, less amphilobe and a much higher percentage of gypsum. Sample To 15 (soil) contains much less muscovite, feldspar, and gynsum than the samples from the structure but shows a higher percentage of illite and kaolinite. In addition, the diffraction pattern of the soil sample shows a prominent peak at $\sim 14.7 \AA$. This is characteristic of the (001) reflection of the montmorillonite group of clay minerals.

The clay size fraction $(<2 \mu \mathrm{m})$ was separated from five Tumacacori specimens by sedimentation. Both oriented and unoriented x-ray sample mounts were prepared. All samples were glycolated to test for the characteristic swelling of minerals of the montmorillonite group. Analytical results are given in Table 3 . The minerals are listed in decreasing order of abundance. 
Table 3. Major Minerals in the $<2 \mu \mathrm{m}$

Fractions of Tumacacori Adobe

SPECIMEN

NUMBER

$$
\begin{aligned}
& \mathrm{To}_{10} \\
& \mathrm{To}_{12} \\
& \mathrm{To}_{15} \\
& \mathrm{To}_{17} \\
& \mathrm{To}_{18}
\end{aligned}
$$

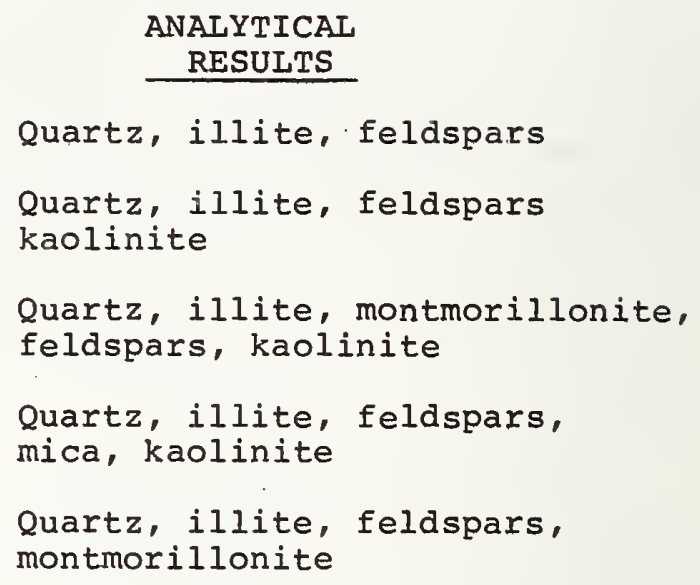


3.3.3 Particle Size Distribution Analysis

Specimens $\mathrm{To}_{10}, \mathrm{To}_{18}$ and $\mathrm{To}_{15}$ were selected for size fraction analysis. Descriptions of the mineral and rock fragments of the various size fractions are given in Tables 4, 5 and 6. Components are listed in decreasing apparent order of abundance. The rock fragments of soil speciment To ${ }_{15}$, are similar to those of To 10 and $\mathrm{To}_{18}$

The organic matter observed in the adobe from Tumacacori consisted of twigs and what appeared to be fragments of grass or straw. In all instances there was a larger amount of organic matter present in adobe material from the structure than from the soil sample. While this is not a conclusive indication that it was added intentionally, this possibility cannot be excluded.

The adobe of Tumacacori is composed primarily of residual fragments of igneous rocks (granites) and their products of chemical weathering. However, the samples examined showed some variability on both the micro- and macro-scale. With decreasing grain size the weathered rock fragments are gradually replaced by individual mineral grains, primarily quartz and feldspars with minor amounts of mica, amphibole, magnetite, titanite, gypsum and perhaps calcite $(-30+50$ mesh). At $-270+400$ mesh, angular quartz is the dominant mineral and remains the major mineral with decreasing grain size even in the clay size fraction. The feldspar grains in the $-270+400$ mesh fraction are subangular to rounded and chemically weathered with clay crystals on their surfaces. With further decreases in particle size, the percentages of true clay minerals gradually increase.

Quartz is the dominant phase in the clay size $(<2 \mu \mathrm{m})$ fraction of the five Tumacacori specimens studied (Table 3). The mineral assemblages are all quite similar. Traces of kaolinite, micas and montmorillonite are probably present in all samples but in amounts beyond the limits of detection by $x$-ray analysis.

The nontmorillonite observed in the bulk samples of $\mathrm{To}_{15}$ and $\mathrm{To}_{18}$ has an (001) d-spacing of $214.7 \AA$ which expands to $\sim 17 \AA$ with glycolation. It is present as a minor mineral in sample $\mathrm{To}_{18}$ but is present in sample To 15 in amounts easily detectable by x-ray analysis, since the bulk soil sample contains a larger clay fraction than the samples from the structure.

Clay mineralogy affects the stability of adobe because of the marked effect of clay on the physical properties of soils and soil materials. In particular clay mineralogy affects expansion and variations in cohesiveness and plasticity of soils as a function of moisture content. These effects result primarily from the property of clay minerals to attract and hold water directly on the clay-particle surfaces. In the case of the swelling clays, such as montmorillonite, incorporation of interlayer water is accompanied by a large increase in volume. The amount of clay in Tunacacori adobe is relatively small ( $8-12$ wt. \%). ; rontmorillonite was detectable in only one of the adobe specimens from the structure $\left(\mathrm{To}_{18}\right)$ and is present in this specimen in only minor amounts. It may be concluded, therefore, that the effects of the presence of a swelling clay on the plysical properties of Tumacacori adobe are minor. 
Table 4. Tumacacori $\left(\mathrm{To}_{10}\right)$ Size Fraction Analysis

\begin{tabular}{lccc}
\hline $\begin{array}{l}\text { Size Fraction } \\
\begin{array}{l}\text { Mesh Per Inch } \\
\text { (U.S. Standard) }\end{array}\end{array}$ & $\begin{array}{c}\text { Percent } \\
\text { of Sample } \\
\text { Weight }\end{array}$ & X-ray Analysis & Remarks \\
\hline $\begin{array}{c}\text { Gravel: } \\
+\end{array}$ & 1.39 & \\
$-4 \quad+8$ & 3.79 & $\begin{array}{l}\text { Angular to subrounded } \\
\text { grains of quartz and of } \\
\text { weathered granites. } \\
\text { Occasional rounded } \\
\text { quartzite grains. }\end{array}$
\end{tabular}

$\begin{array}{ll}\frac{\text { Sand: }}{-8}+16 & 5.99 \\ -16+30 & 8.57\end{array}$

$-16+30 \quad 8.57$

$-30+50$

9.52

$-50+100$

8.48

8.26

$-100+200$

8.26

$-200+270$

6.79

$-270+400$

6.45

$-400+20 u m$

16.67

silt

$(-20 \mu \mathrm{m}+2 \mu \mathrm{m})$

12.67

clay

$(<2 \mu \mathrm{m})$

11.24

Organic

0.18

Soluble

Salts

1.26
Feldspars, quartz, mica, amphibole.

Quartz, feldspars

Quartz, feldspars, mica, amphibole

" "

Quartz, feldspars, mica, amphibole (trace)

Quartz, feldspars, mica, illite amphibole (trace)

Quartz, feldspars, mica, and illite

Quartz, illite, feldspars
Angular grains of weathered granites, many with biotite, angular to subrounded grains of clear and milky quartz.

Individual grains of feldspars and amphibole also present. Granite fragments decreasing in amounts.

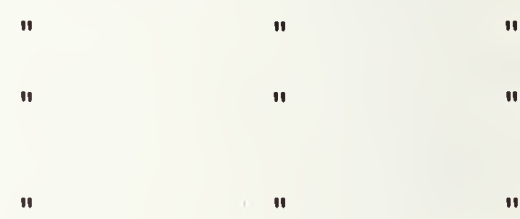

Angular quartz is the dominant mineral. Feldspars and mica decreasing.

"

11

Twigs, grass

Primarily $\mathrm{CaSO}_{4} \cdot 2 \mathrm{H}_{2} \mathrm{O}$ and $\mathrm{CaCl}_{2}$ (chlorides and sulfates of $\mathrm{Na}, \mathrm{K}$, and $\mathrm{Mg}$ likely) 
Table 5. Tumacacori $\left(\mathrm{To}_{18}\right)$ Size Fraction Analysis

\begin{tabular}{|c|c|c|c|c|}
\hline $\begin{array}{l}\text { Size F } \\
\text { Mesh F } \\
\text { (U.S. }\end{array}$ & $\begin{array}{l}\text { Fraction } \\
\text { Per Inch } \\
\text { Standard) }\end{array}$ & $\begin{array}{l}\text { Percent } \\
\text { of Sample } \\
\text { Weight }\end{array}$ & X-ray Analysis & Remarks \\
\hline \multicolumn{5}{|c|}{ Gravel: } \\
\hline & +4 & 2.25 & & $\begin{array}{l}\text { Rounded to subangular } \\
\text { grains of quartz and }\end{array}$ \\
\hline-4 & +8 & 4.35 & & $\begin{array}{l}\text { weathered granites. } \\
\text { Occasional rounded } \\
\text { grains of quartzite. }\end{array}$ \\
\hline$\frac{\text { Sand: }}{-8}$ & +16 & 9.37 & & $"$ \\
\hline-16 & +30 & 13.05 & $\begin{array}{l}\text { Feldspars, quartz, } \\
\text { mica }\end{array}$ & $\begin{array}{l}\text { Quartz grains increasing } \\
\text { relative to rock frag- } \\
\text { ments }\end{array}$ \\
\hline-30 & +50 & 12.05 & $\begin{array}{l}\text { Feldspars, quartz, } \\
\text { mica }\end{array}$ & $\begin{array}{l}\text { Individual feldspar } \\
\text { grains and mica flakes, } \\
\text { angular quartz. Rock } \\
\text { fragments decreasing }\end{array}$ \\
\hline-50 & +100 & 8.89 & $\begin{array}{l}\text { Feldspars, quartz, } \\
\text { mica }\end{array}$ & $"$ \\
\hline-100 & +200 & 8.40 & $\begin{array}{l}\text { Feldspars, quartz, } \\
\text { mica, amphibole }\end{array}$ & $"$ \\
\hline-200 & +270 & 5.91 & " " & . \\
\hline-270 & +400 & 4.86 & $"$ & $\begin{array}{l}\text { Angular quartz is the } \\
\text { dominant mineral }\end{array}$ \\
\hline-400 & $+20 \mu \mathrm{m}$ & 11.88 & $\begin{array}{l}\text { Quartz, feldspars, } \\
\text { mica, illite, amphi- } \\
\text { bole }\end{array}$ & $"$ \\
\hline $\begin{array}{l}\text { Silt } \\
(-20 \mu \mathrm{m}\end{array}$ & $m+2 \mu m)$ & 9.07 & $\begin{array}{l}\text { Quartz, feldspars, } \\
\text { mica, illite, amphi- } \\
\text { bole }\end{array}$ & $"$ \\
\hline $\begin{array}{l}\text { Clay } \\
(<2 \mu \mathrm{m})\end{array}$ & ) & 9.02 & $\begin{array}{l}\text { Quartz, illite, feld- } \\
\text { spars, montmorillonite }\end{array}$ & $"$ \\
\hline Organi & & 0.21 & & Twigs and grasses \\
\hline $\begin{array}{l}\text { Solubl } \\
\text { Salts }\end{array}$ & & 0.37 & & \\
\hline
\end{tabular}


Table 6. Tumacacori Soil Sample $\left(\mathrm{TO}_{15}\right)$ Size Fraction Analysis

\begin{tabular}{|c|c|c|c|}
\hline $\begin{array}{l}\text { Size } \\
\text { Mesh } \\
\text { (U.S. }\end{array}$ & $\begin{array}{l}\text { Fraction } \\
\text { Per Inch } \\
\text { Standard) }\end{array}$ & $\begin{array}{l}\text { Percent } \\
\text { of Sample } \\
\text { Weight }\end{array}$ & $\mathrm{X}$-ray Analysis \\
\hline Grave & $\begin{array}{l}1: \\
+4\end{array}$ & 0.18 & \\
\hline-4 & +8 & 0.97 & \\
\hline$\frac{\text { Sand: }}{-8}$ & +16 & 0.85 & \\
\hline-16 & +30 & 1.06 & Feldspars, quartz, mica \\
\hline-30 & +50 & 1.64 & $"$ \\
\hline-50 & +100 & 1.58 & 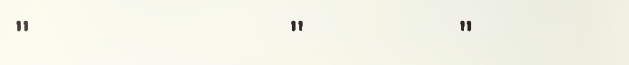 \\
\hline-100 & +200 & 1.68 & $\begin{array}{l}\text { Feldspars, quartz, mica } \\
\text { amphibole }\end{array}$ \\
\hline-200 & +270 & 1.59 & $"$ \\
\hline-270 & +400 & 1.10 & $"$ \\
\hline-400 & $+20 \mu \mathrm{m}$ & 5.89 & 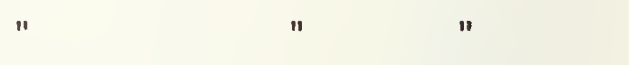 \\
\hline $\begin{array}{l}\text { Silt } \\
(20 \mu \mathrm{m}\end{array}$ & $+2 \mu \mathrm{m})$ & 37.74 & $\begin{array}{l}\text { Quartz, feldspars, mica, } \\
\text { illite (trace), montmoril- } \\
\text { lonite (trace) }\end{array}$ \\
\hline $\begin{array}{l}\text { Clay } \\
(<2 \mu \mathrm{m}\end{array}$ & & 45.54 & $\begin{array}{l}\text { Quartz, illite, montmotil- } \\
\text { lonite, feldspars, kaolinite, } \\
\text { mica }\end{array}$ \\
\hline Organ & & $\mathrm{Nil}$ & \\
\hline $\begin{array}{l}\text { Solub } \\
\text { Salts }\end{array}$ & & 0.17 & \\
\hline
\end{tabular}




\subsubsection{Soluble salt Analyses}

Soluble salt fractions from four Tumacacori specimens (To 10 " To 11 ' $\mathrm{To}_{15}$ and $\mathrm{To}_{16}$ ) were separated for qualitative elemental analysis by energy dispersive $x$-ray analysis. Analytical results are given in Table 7. The elements are lister. in decreasing order of elemental abundance.

Table 7. Flemental Analysis of Soluble Salts in Tumacacori Adobe

\begin{tabular}{|c|c|c|}
\hline $\begin{array}{l}\text { Specimen } \\
\text { Number }\end{array}$ & $\begin{array}{l}\text { Soluble Salt } \\
\text { Content as a } \\
\text { Percentage of } \\
\text { Sample Weight }\end{array}$ & Analytical Results* \\
\hline $\mathrm{To}_{10}$ & 1.26 & $\begin{array}{l}\mathrm{S}, \mathrm{Ca}, \mathrm{Cl}, \mathrm{K}, \mathrm{Si} \text { and trace } \\
\text { amounts of } \mathrm{ilg}^{\mathrm{A}} \mathrm{Al}, \text { and } \mathrm{Na}\end{array}$ \\
\hline $\mathrm{To}_{11}$ & $8.78 * *$ & $\mathrm{Ca}, \mathrm{Cl}, \mathrm{K}, \mathrm{S}, \mathrm{Mg}$ \\
\hline $\mathrm{To}_{15}$ & 0.17 & $\begin{array}{l}\mathrm{K}, \mathrm{Cl}, \mathrm{S}, \mathrm{Ca}, \mathrm{Si}, \mathrm{Mg}, \text { and } \\
\text { trace amounts of } \mathrm{Na}, \mathrm{Al} \text {, and } \mathrm{P}\end{array}$ \\
\hline $\mathrm{To}_{16}$ & 5.78 & $\begin{array}{l}\mathrm{Ca}, \mathrm{K}, \mathrm{Mg}, \mathrm{Cl}, \mathrm{S} \text { and a trace } \\
\text { amount of } \mathrm{si}\end{array}$ \\
\hline $\mathrm{To}_{18}$ & 0.37 & Not analyzed \\
\hline $\begin{array}{l}\text { * Based } \\
\text { * As a E }\end{array}$ & \multicolumn{2}{|c|}{$\begin{array}{l}\text { analyses of each specimen. } \\
\text { weight of the }-50 \text { mesh fraction }\end{array}$} \\
\hline
\end{tabular}

A quantitative analysis of the composition of the salts obtained from Specimen To 11 was carried out to determine the relative amounts of the major species present. This was accomplished using ion-selective electrodes in combination with gravimetric techniques. The results of this analysis are given in Table 8.

Although the relative amounts of each differed, calcium, sulfur, potassium, and chlorine were observed in all salts, no attempt was made to identify the compounds present by $\mathrm{x}$-ray analysis. However, $\mathrm{CaSO}_{4} \cdot 2 \mathrm{H}_{2} \mathrm{O}$ and $\mathrm{CaCl}_{2}$ were identified in specimen $\mathrm{TO}_{11}$ by SFM-EDXA. The hygroscopic nature of the salts was examined by measuring their weight gains on equilibration with air at $23^{\circ} \mathrm{C}$ and $35 \% \mathrm{r} . \mathrm{h}$. after drying to constant weight at $105^{\circ} \mathrm{C}$. The salts from sample To ${ }_{10}$ exhibited a weight gain of about $21 \%$ while those from To $_{11}$ and ${ }^{\circ}{ }_{16}$ gained 59\% and 63\%, respectively. Sufficient water was taken up by the salts from To 11 and $\mathrm{To}_{16}$ to cause them to appear as viscous fluids as illustrated in Figure 11 . 
Table 8. Analysis of Salts Extracted from

specimen To 11

Chemical

Species

$\mathrm{K}^{+}$

$\mathrm{Na}^{+}$

$\mathrm{Mg}^{++}$and $\mathrm{Ca}^{++}$

$\mathrm{Cl}^{-}$

$\mathrm{SO}_{4}=$

$\mathrm{H}_{2} \mathrm{O}$ (as water of hydration ${ }^{\neq}$
Weight

Percent

19.5

0.6

16.0

12.4

20.2

31.3

f Includes weights of species present in trace amounts.

Gypsum was observed in all of the Tumacacori adobe samples. Small white particles or pore fillings in sample To 17 , believed to be gypsum, but too fine to be separated were examined by energy dispersive $x$-ray analysis. An SEM Ca-S map confirmed the presence of gypsum. Figure 12 shows the distribution of these fine particles at $10 \mathrm{x}$ magnification. When the gypsum just fills the pores and channels of the adobe, it may leave the matrix undisturbed and in fact have a cementing effect. This was observed in To 16 which was very well consolidated in spite of being wet. However, when the gypsum crystals greatly exceed the size of the pores, such as in sample To 11 ' they displace the clay-silt matrix in their immediate vicinity and may cause a disruption of the matrix as stresses produced by crystal growth are relieved. Cyclic wetting and drying exacerbate this effect through the dissolution and regrowth of these crystals.

The effects of freeze-thaw damage may also be more severe in the presence of soluble salts. The hygroscopic nature of salts such as $\mathrm{MgCl}_{2}$ ' $\mathrm{MgSO}_{4}$, or $\mathrm{CaCl}_{2}$ causes the retention of water within the structure. If this water freezes, disrupture effects can occur dur to ice crystaljization. In addition, the freezing of water facilitates salt crystallization. $\Lambda s$ a result, cyclic dissolution and regrowth of salt crystals can occur with changes in temperature as well as with changes in the absolute moisture content within an adobe structure.

The soil sample, To 15 , and sample To 18 were found to contain 0.17 and 0.37 wto soluble salts, respectively, while samples To $10^{\prime} \mathrm{To}_{11^{\prime}}$ and To 16 contained much higher salt concentrations (see Table 7). This salt buildup is indicative of the migration of ground water into parts of the structure. Elemental analysis of the salt compositions indicated the presence of gypsum. 
This was not unexpected since the nave walls were originally covered with a gypsum wash. However, the high concentrations of gypsum observed in the bulk material indicate the movement of water within the body of the structure. Analyses also revealed the presence of alkalies and chloride ions indicating that rising ground water is carrying these ions into the structure. As this water evaporates, the salts are left behind, either at the surface (efflorescence) or immediately below it (subflorescence). Their presence ultimately leads to severe disruption of the adobe matrix either through crystal growth, as in the case with gypsum, or due to their deliquescence, as in the case with calcium or magnesium chlorides, or both. Both effects occur in certain portions of Tumacacori and appear to be the major cause of deterioration of portions of the interior nave wall.

\subsubsection{Summary}

The degree of consolidation observed in the various adobe samples from Tumacacori correlated with the concentrations of soluble salts present. Samples taken from a number of locations in the structure were relatively uniform in mineralogical composition and particle size distribution. The soil sample, however, was found to be high in silt and clay, suggesting that the coarser fractions were intentionally added to achieve the desired proportioning. The distinctive feature of Tumacacori adobe is the chemical zoning of the feldspars.

4. POROSITY ANALYSES OF TUMACACORI, FORT BOWIE, AND ESCALANTE RUIN

The weathering of adobe is closely related to the effects of moisture; therefore, the durability of an adobe may be expected to be closely related to its porosity. As a consequence, density and porosity measurements were carried out on selected adobe samples. In addition the particle size distributions in the silt and clay-size fractions were analyzed. Densities were determined by helium pycnometry while porosities were determined using mercury intrusion porosimetry. The density and porosity data are summarized in Table 9, and the pore size distributions are shown in Figure 13. In this figure the percentage of total porosity is plotted as a function of pore diameter. The porosity data presented in Table 9 and Figure 13 are confined to pores with diameters between 177 and $0.0035 \mu \mathrm{m}$. The nature of the distributions of large diameter pores (voids) in these specimens is mentioned in the preceeding sections. 
Table 9. Densities and Porosities of Selected Adobe Samples

\begin{tabular}{ccccc}
\hline $\begin{array}{c}\text { Sample } \\
\text { Designation }\end{array}$ & $\begin{array}{c}\text { Density } \\
\text { grams/cc }\end{array}$ & $\begin{array}{c}\text { Net Pore } \\
\text { Volume } \\
\text { cc/grams }\end{array}$ & $\begin{array}{c}\text { Average } \\
\text { Pore } \\
\text { Diameter } \\
\mu \mathrm{m}\end{array}$ & $\begin{array}{c}\text { Measured } \\
\text { Total Porosity* }\end{array}$ \\
\hline To $_{10}$ & 2.56 & 0.233 & 4.2 & 37.4 \\
To $_{11}$ & 2.56 & 0.213 & 14.0 & 34.5 \\
To $_{12}$ & 2.60 & 0.199 & 2.5 & 33.9 \\
To $_{17}$ & 2.46 & 0.318 & 4.8 & 43.0 \\
Fort Bowie & 2.68 & 0.150 & 3.4 & 27.9 \\
Escalante & 2.80 & 0.227 & 2.8 & 38.2
\end{tabular}

*size range $177-0.0035 \mu \mathrm{m}$

The densities of the adobes listed in Talle 9 are somewhat variable, however, densities of the adobe samples from Tumacacori do not vary appreciably, differing at most by 5.7\%. Similarly, the average pore diameters observed in these samples does not vary greatly, with the exception of To ${ }_{11}$. A larger average pore diameter in To 11 may be attributable to the disruptive affects of salt action. Cyclic dissolution and recrystallization of salt and water in the pores appears to alter the internal porosity distribution; total measured porosity does not appear to increase and may, in fact, decrease dur to space filling by salt crystals.

The total measured porosities of the adobes from the three sites cover a rather broad range from about $28 \%$ to $43 \%$. There is not a direct correlation with the degree of weathering. For example, the Fort Bowie corral is severely weathered yet this sample shows the smallest total measured porosity. However, a comparison of the porosities of samples from Tumacacori may be qualitatively correlated. Sample To ${ }_{10}$ ' from the top of an exposed wall, and To $17^{\prime}$ from an exterior location, show the highest measured porosity, yet the porosity from To 10 which has been subjected to more severe weathering conditions (See Table 10) is lower. It should be pointed out, however, that variations in the original proportioning of these adobes along with the amount of water used would have a significant effect on their total porosities.

The particle size distributions of the samples listed in Table 9 vere determined using a sedimentation technique. These analyses were limited to particles which passed a $75 \mu \mathrm{m}$ sieve and were carried out to examine the size distribution within the silt and clay size fractions. Table 10 summarizes the data shown in Figure 14. Figure 14 plots the cumulative mass percent as a function of particle diameter and shows the relative proportions of silt and 
clay in addition to the distributions of particle sizes. Reference to the samples from Tumacacori indicates that $\mathrm{To}_{10}$ and $\mathrm{To}_{11}$ are deficient in clay when compared with $\mathrm{To}_{12}$ and $\mathrm{TO}_{17}$ ' but contain relatively larger amounts of silt and fine sand (Table 10). Figure 14 shows samples $\mathrm{TO}_{10}$ and $\mathrm{TO}_{11}$ to be

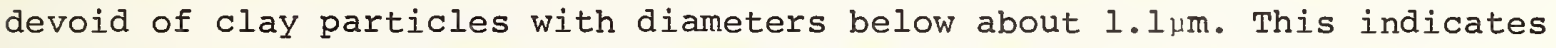
that the weathering of these samples is primarily reflected in the loss of fine clay particles, while their relatively high silt contents may indicate that particles in this size range are less sensitive to the action of water.

Table 10. Particle Size Distribution by Sedimentation

\begin{tabular}{|c|c|c|c|}
\hline $\begin{array}{c}\text { Sample } \\
\text { Designation }\end{array}$ & $\begin{array}{r}\text { Sand } \\
-75+20 \mu \mathrm{m} \\
\end{array}$ & $\begin{array}{c}\% \text { Silt } \\
-20 \mu \mathrm{m}+2 \mu \mathrm{m} \\
\end{array}$ & $\begin{array}{l}\text { Clay } \\
-2 \mu \mathrm{m}\end{array}$ \\
\hline $\mathrm{To}_{10}$ & 22 & 71 & 7 \\
\hline $\mathrm{To}_{11}$ & 10 & 78 & 12 \\
\hline $\mathrm{To}_{12}$ & 14 & 61 & 25 \\
\hline $\mathrm{To}_{17}$ & 6 & 66.5 & 27.5 \\
\hline Fort Bowie & 17 & 61 & 22 \\
\hline Escalante & 18 & 55 & 27 \\
\hline
\end{tabular}

5. SUMMARY AND CONCLUSIONS

Adobe from Escalante Ruin was found to be well consolidated in spite of its high soluble salt content. The high degree of consolidation along with the light color of this material is attributable to the presence of massive amounts of calcite which behaves both as a cementing agent and a pigment.

The adobe from Fort Bowie National Historic Site has a low soluble salt content but exhibits poor resistance to weathering. This was found to be the result of the particle size distribution since this adobe contains a large fraction of gravel and coarse sand but is deficient in the fine, bonding fractions.

The adobe from Tumacacori National Monument showed varying degrees of consolidation. A series of samples from an interior wall showed variable consolidation which was dependent on their soluble salt contents. The presence of soluble salts is indicative of rising ground water and those samples with high salt concentrations showed signs of significant deterioration. Other samples in which less salt was present showed a high degree of consolidation. One sample from an exterior wall was well consolidated in spite of the fact that the action of rain had leached out a significant amount of its fine clay fraction. 
An analysis of the salts present in one deteriorated sample revealed the presence of chlorides and sulfates of calcium and magnesium; of these $\mathrm{MgCl}_{2}$ ' $\mathrm{MgSO}_{4}$ and $\mathrm{CaCl}_{2}$ are hygroscopic salts. The tendency of the salts to retain water leads to deterioration through several processes including cyclic wetting and drying, cyclic salt recrystallization, and freeze-thaw damage.

A comparison of the particle size distribution of a soil sample from the Tumacacori site with those of several samples from the structure suggested that the adobe was deliberately proportioned for use in construction. The church at Tumacacori was built with adobe apparently composed of 1 part of soil diluted with about 4 parts of sand.

Based on the analyses carried out on the adobe from the three sites investigated, it was possible to correlate the type and severity of weathering observed with compositional, particle size distribution, porosity, and soluble salt analyses. Analyses of the mineralogical aspects of the samples studied allowed an assessment of their variability while indicating that the deterioration observed in these samples did not result from the presence of a swelling clay. The combination of these analyses also provides a basis for the selection of adobe repair material which would be representative of that originally used. 
6. REFERENCES

1. J. R. Clifton, Preservation of Historic Adobe Structures - A Status Report, NBS Tech. Note 934, U.S. GPO (1977).

2. J. R. Clifton, P. W. Brown, and C. R. Robbins, Methods for Characterizing the Physicochemical Properties of Adobe Building Materials, NBS Tech. Note. In press. 


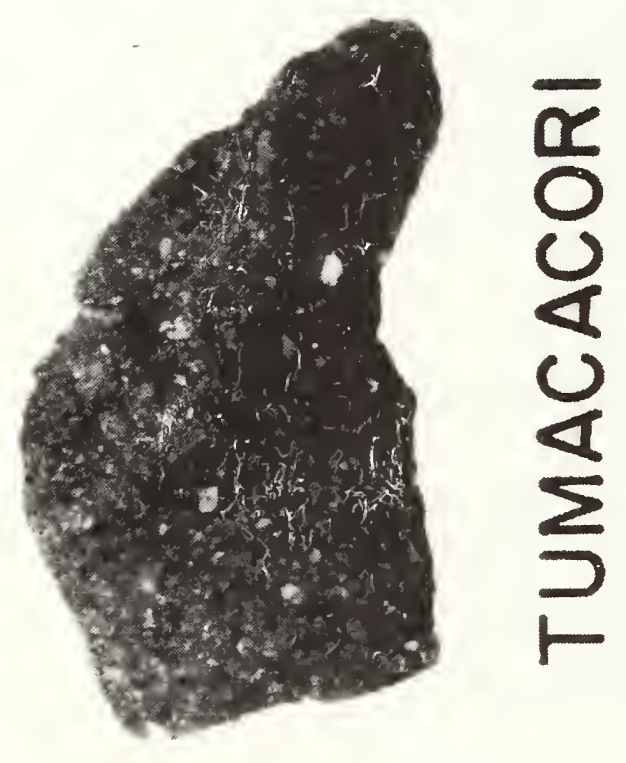

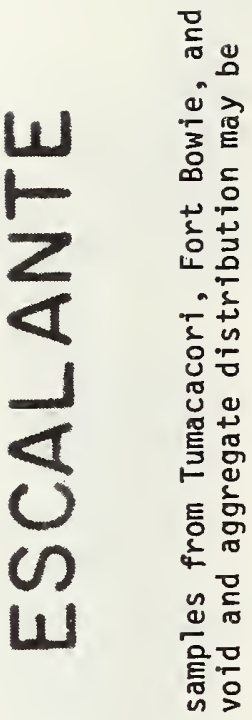

品

\%

ह के

ํํำ

菏

$4 \div$

ㄷํㄴㄴ

의
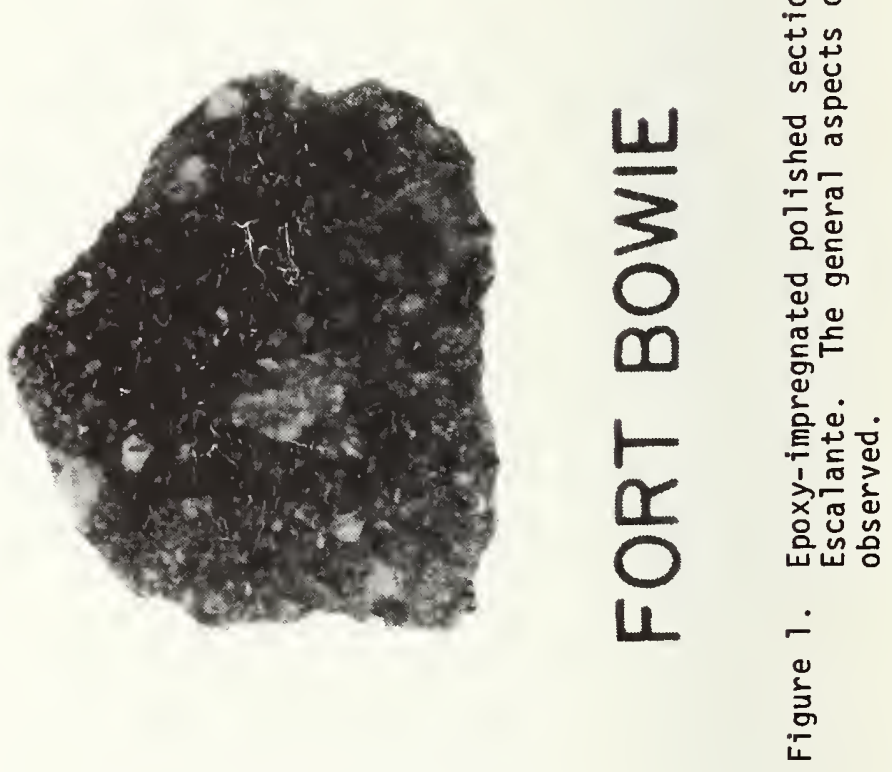


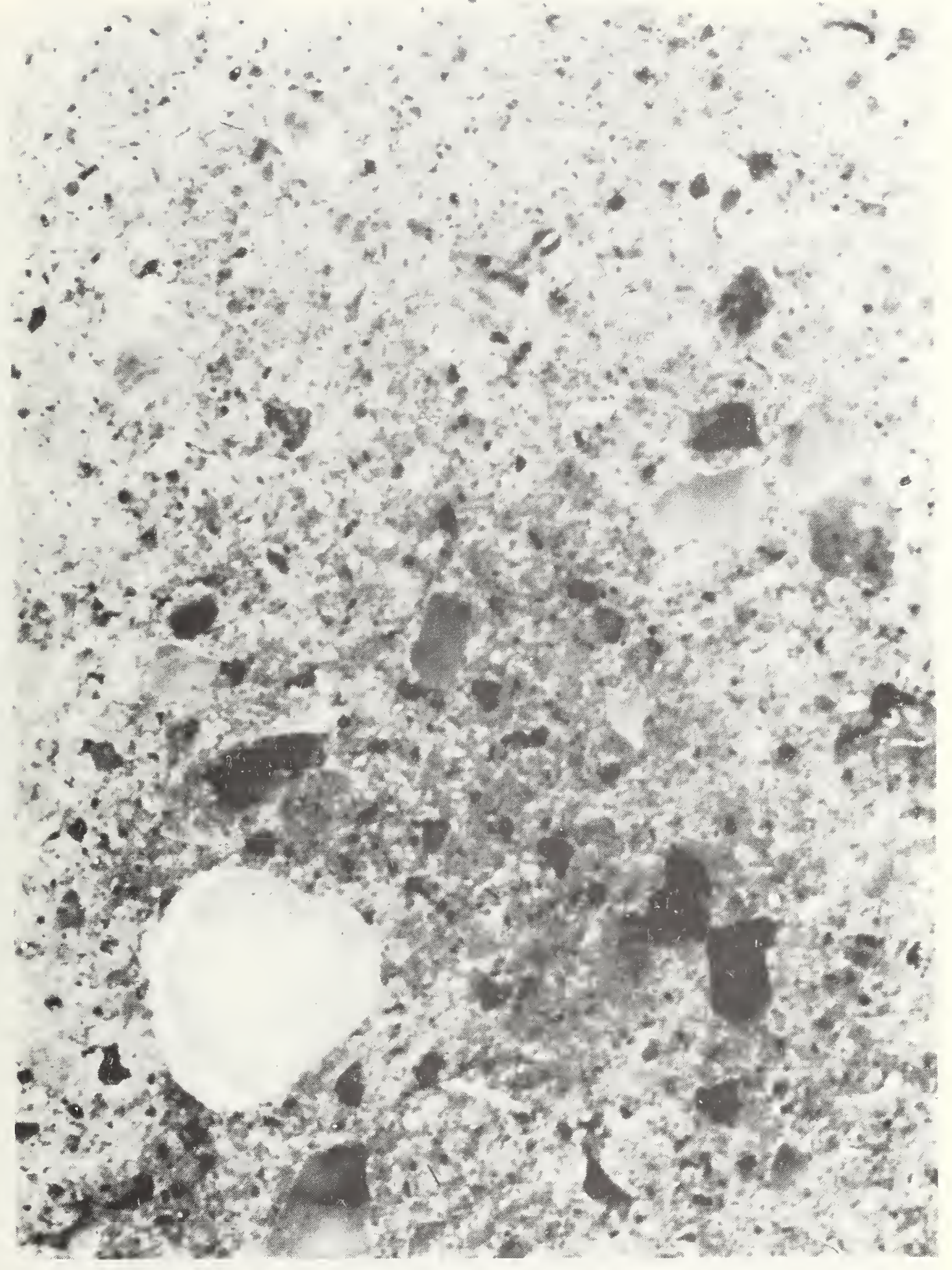

Figure 2. Epoxy-impregnated polished section of adobe from Escalante showing the aggregate distribution in the fine matrix. The light color of the matrix is due to the presence of calcite. lox magnification. 


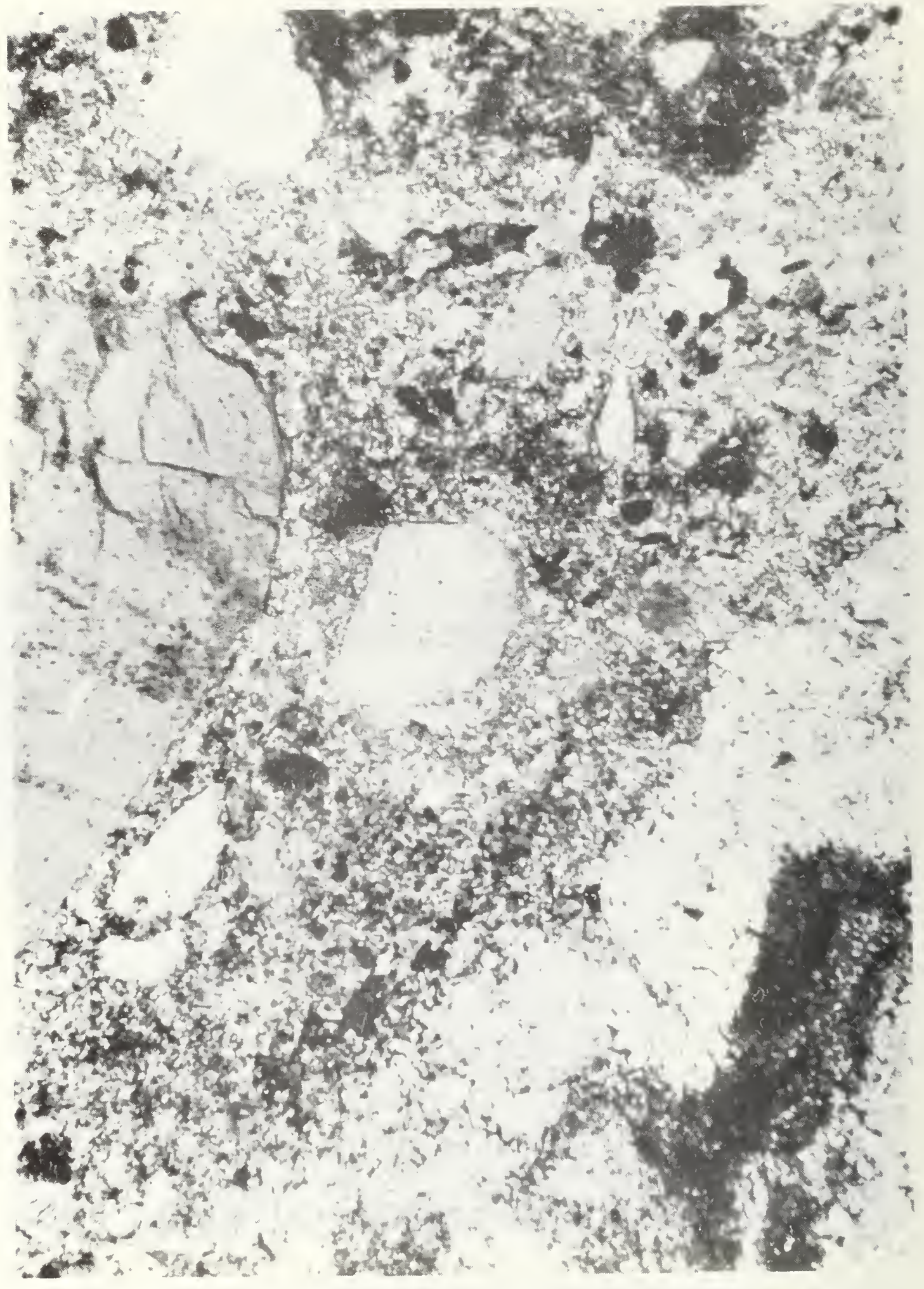

Figure 3. Thin section of adobe from Escalante viewed in transmitted polarized light showing coarse quartz and feldspar grains in their characteristic calcite-clay matrix. 100x magnification 


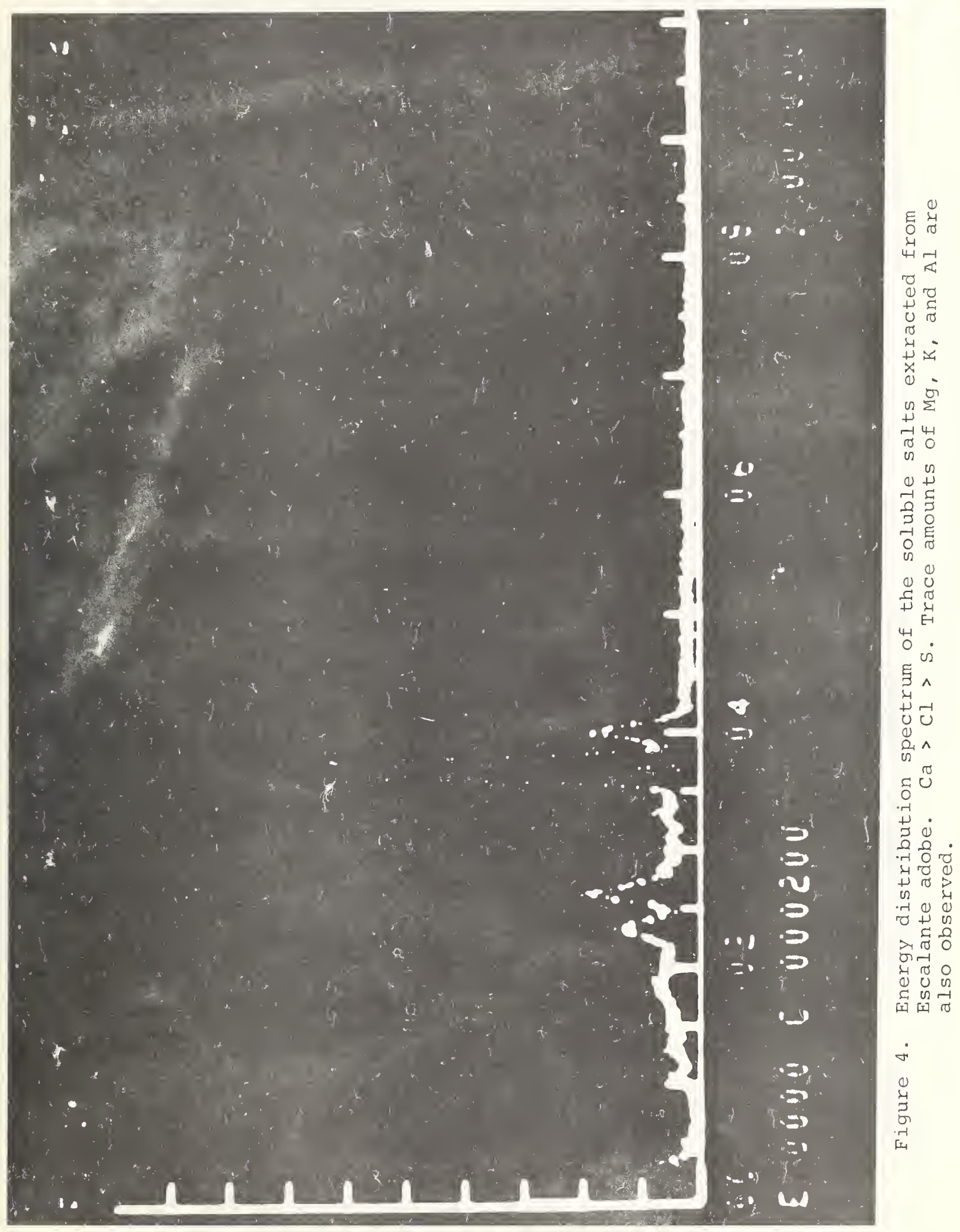




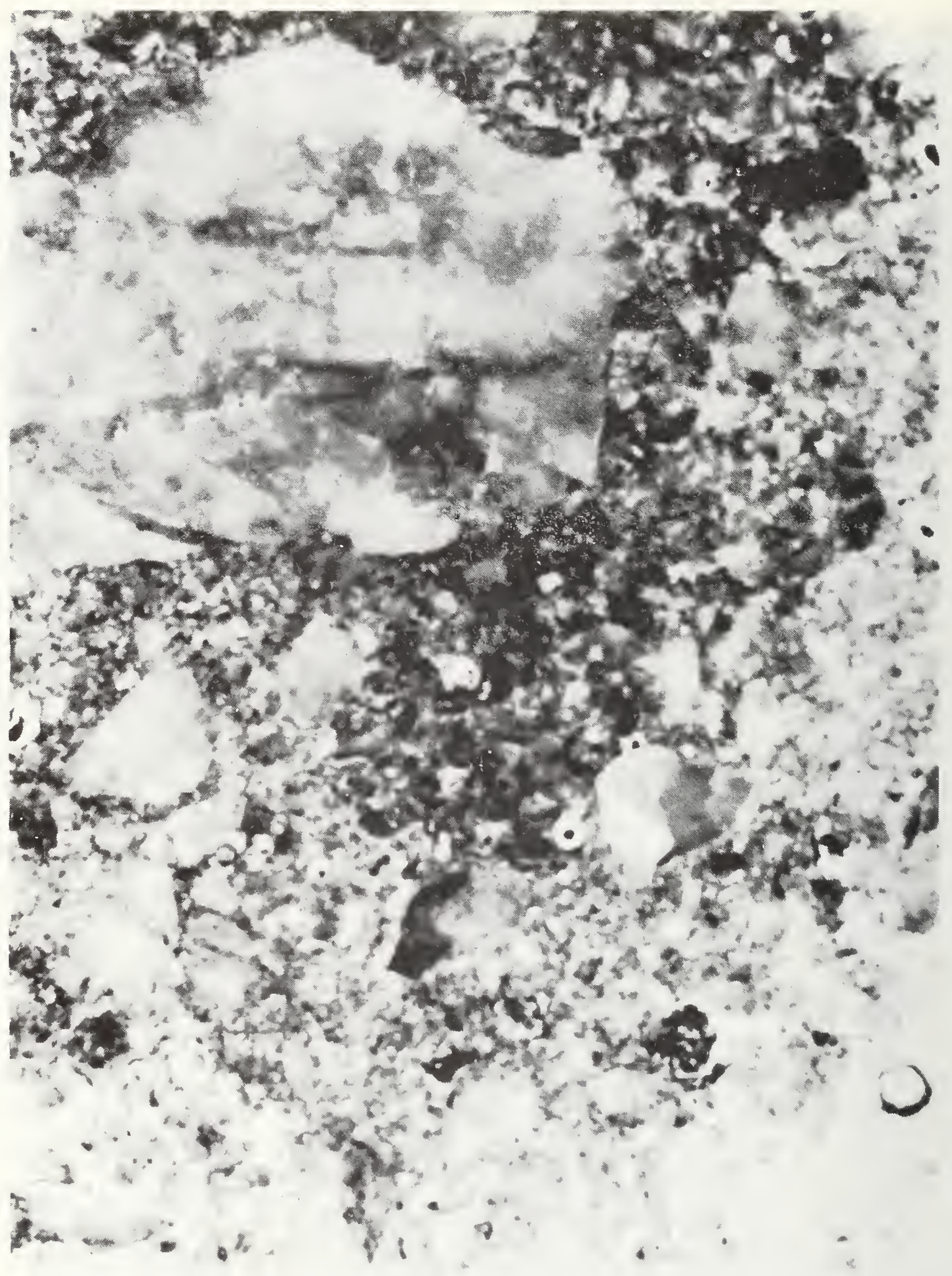

Figure 5. Epoxy-impregnated polished section of adobe from Fort Bowie showing the distribution of aggregate in the matrix. 10x magnification. The size of the aggregate in this adobe as compared to that in Escalante (Figure 2) or Tumacacori (Figure 8) is noteworthy. 


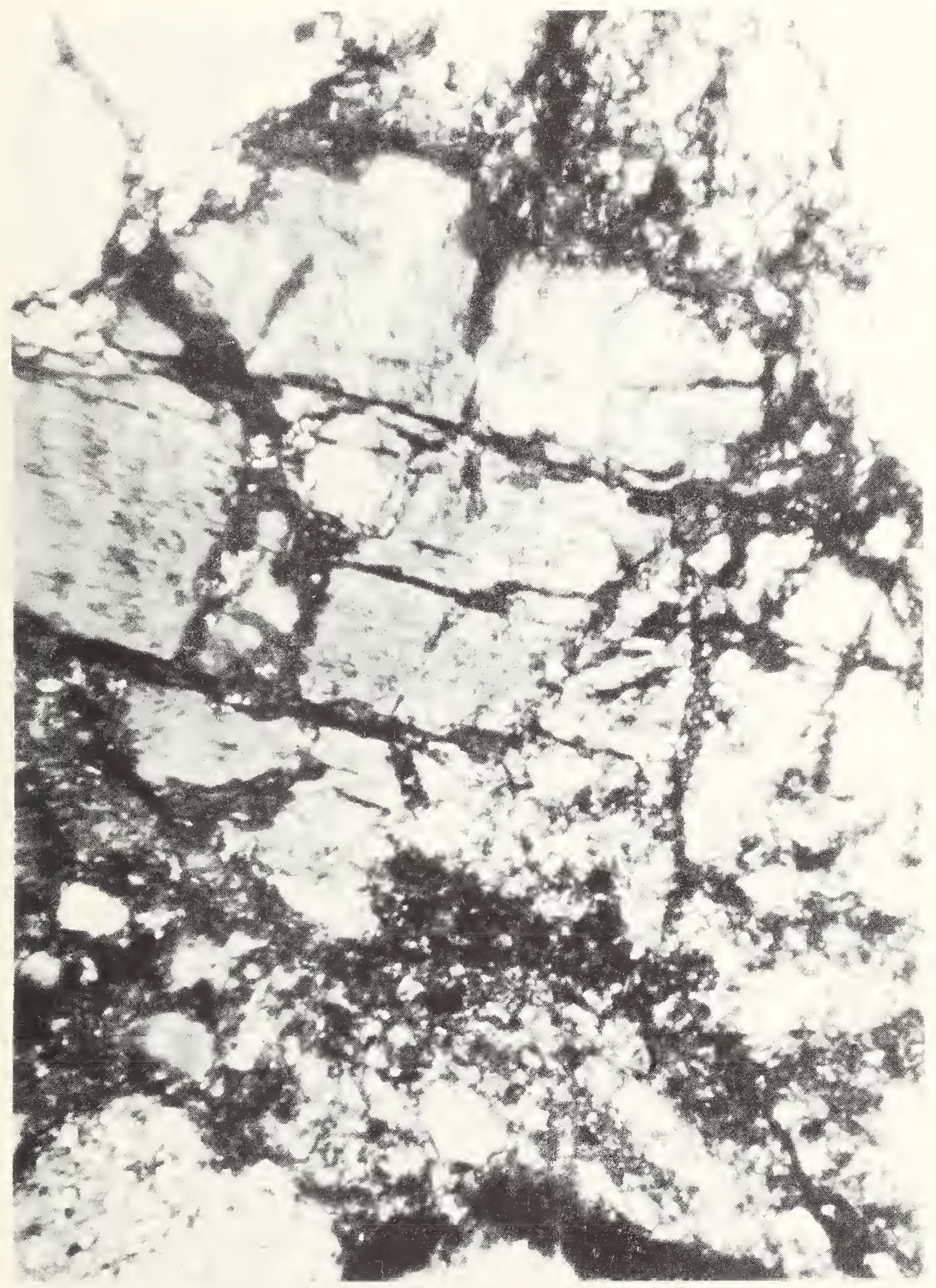

Figure 6. Thin section of adobe from Fort Bowie viewed in transmitted polarized light showing large aggregate grains separated by narrow regions of silt-clay matrix. 50x magnification. This feature is distinctive of this adobe. 


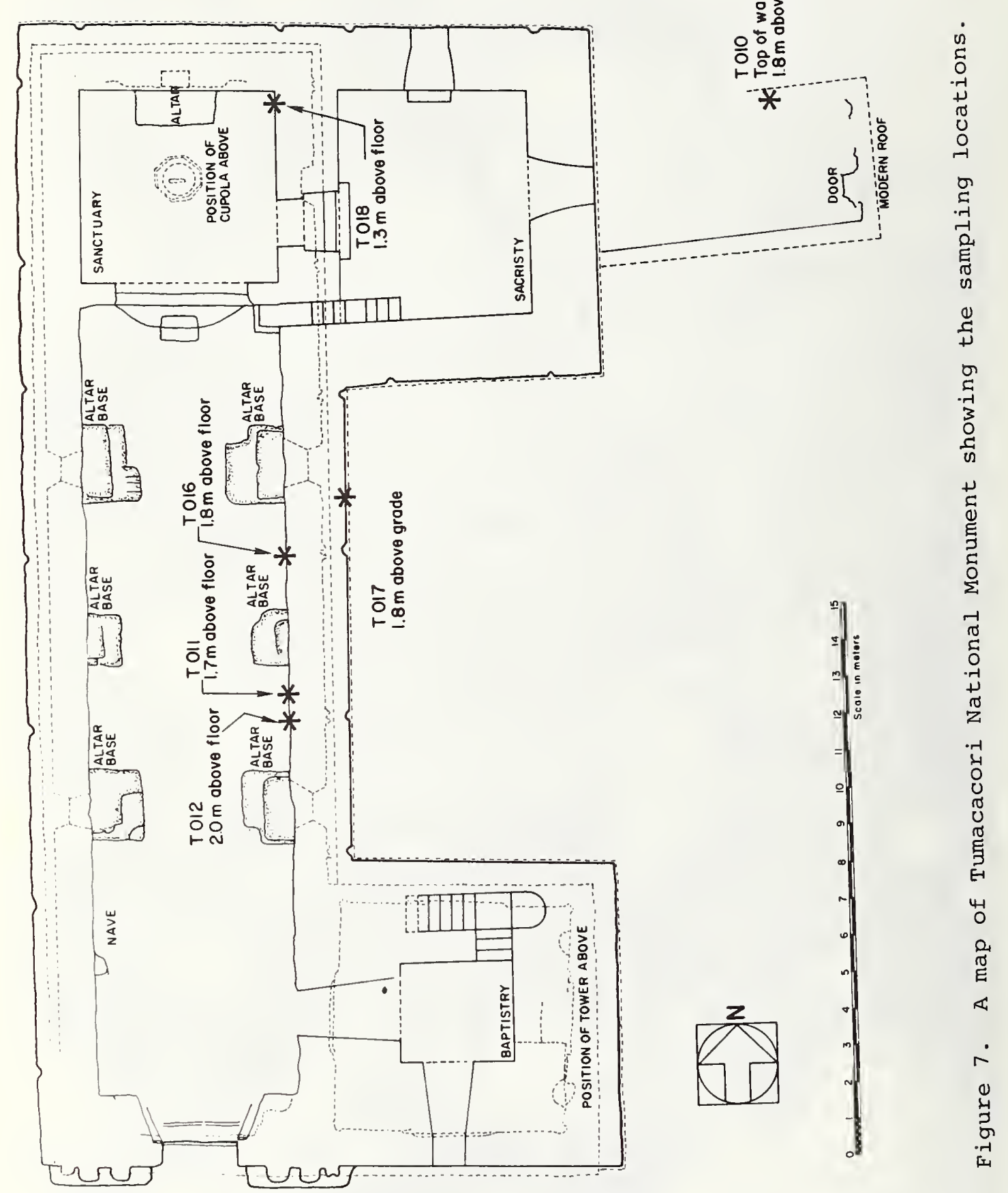




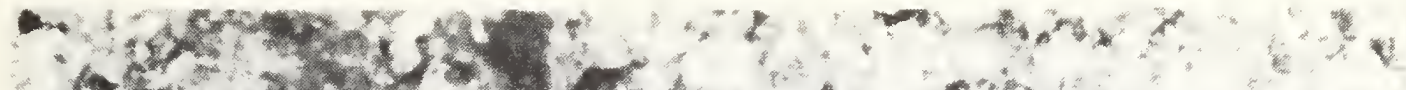

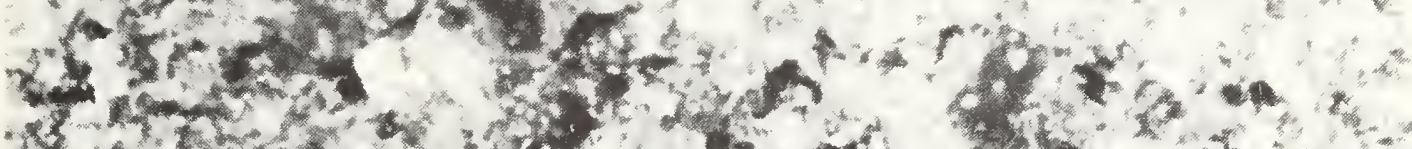

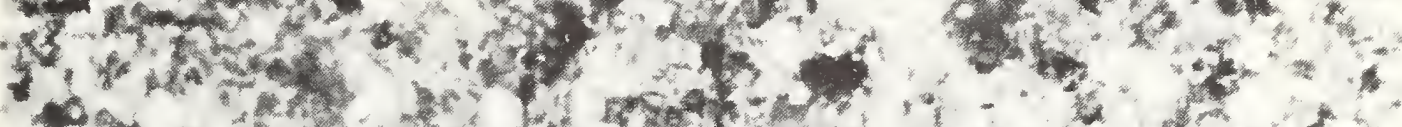

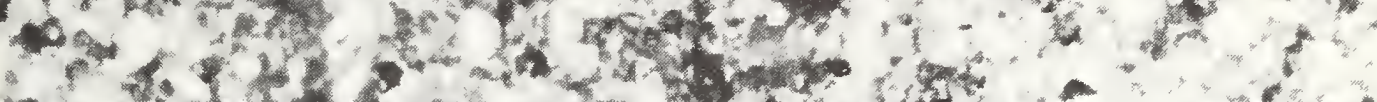

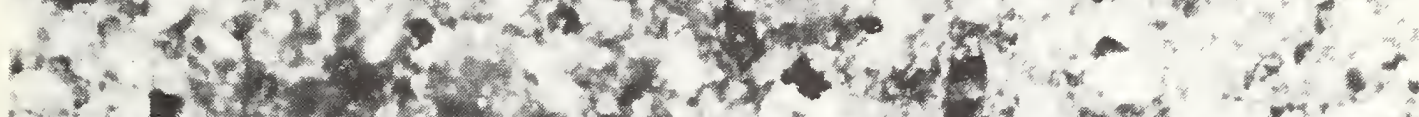
- che

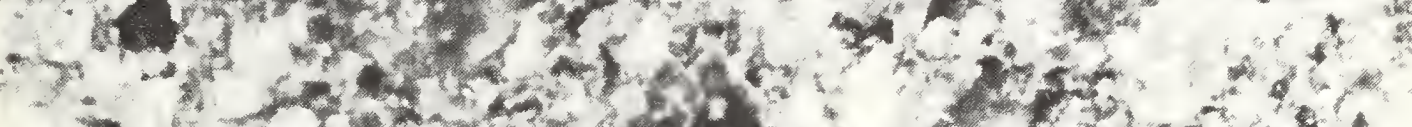

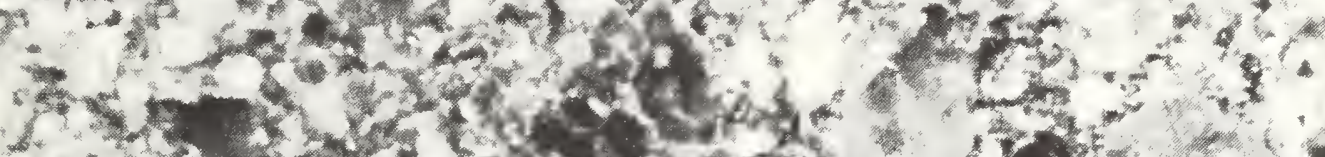

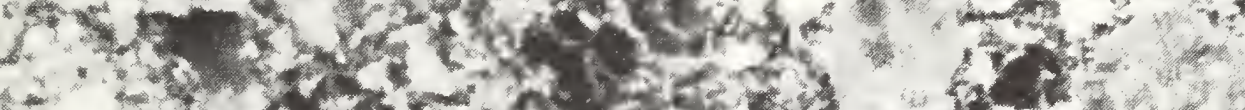

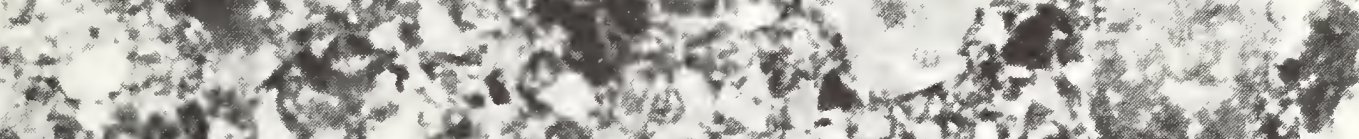

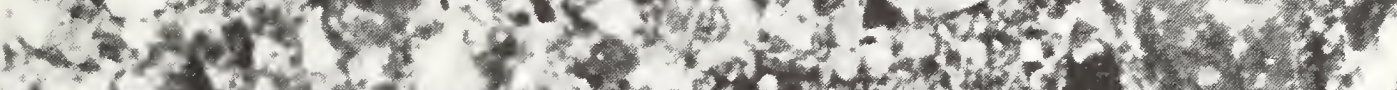

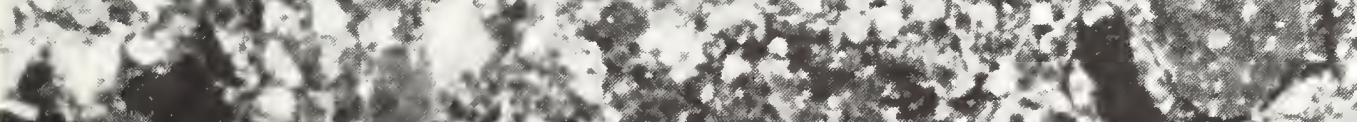

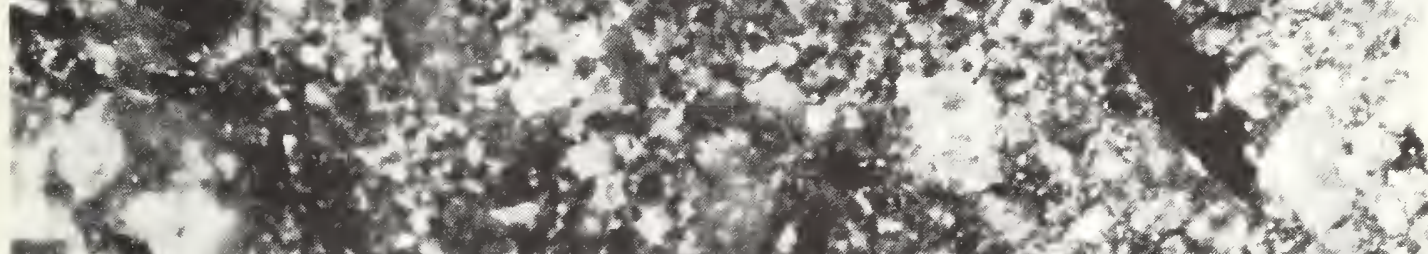

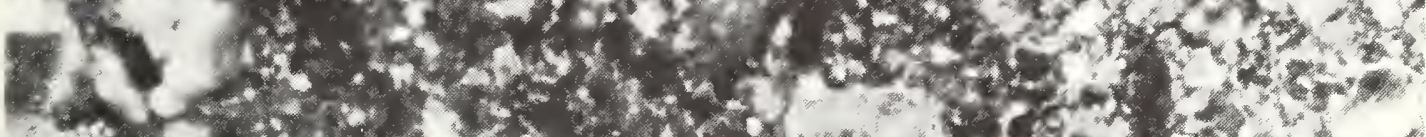

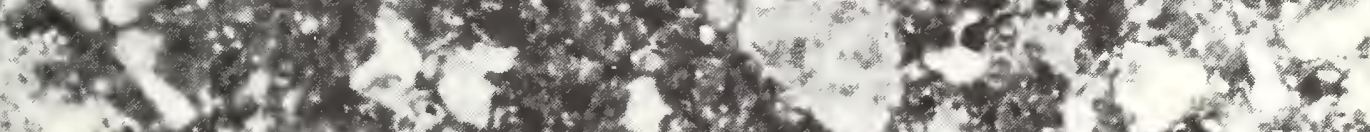

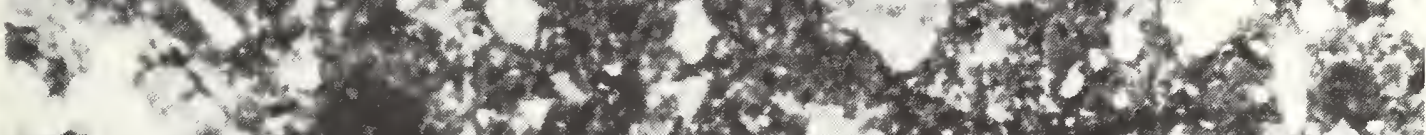

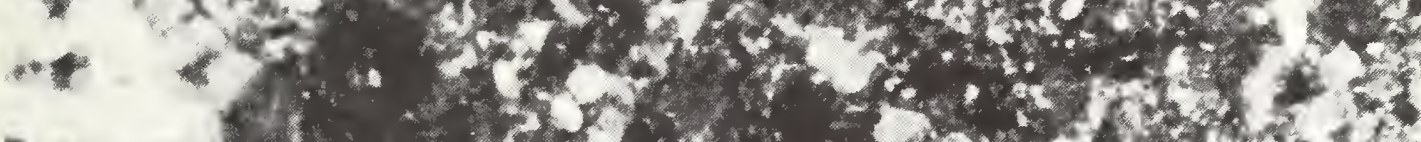

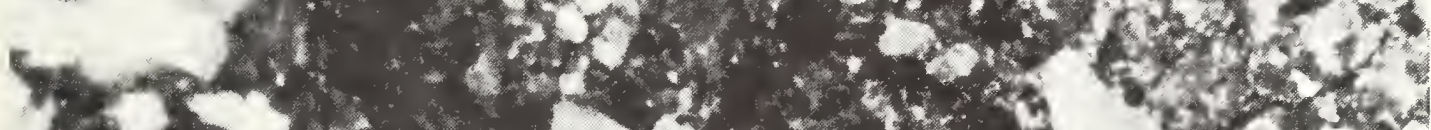

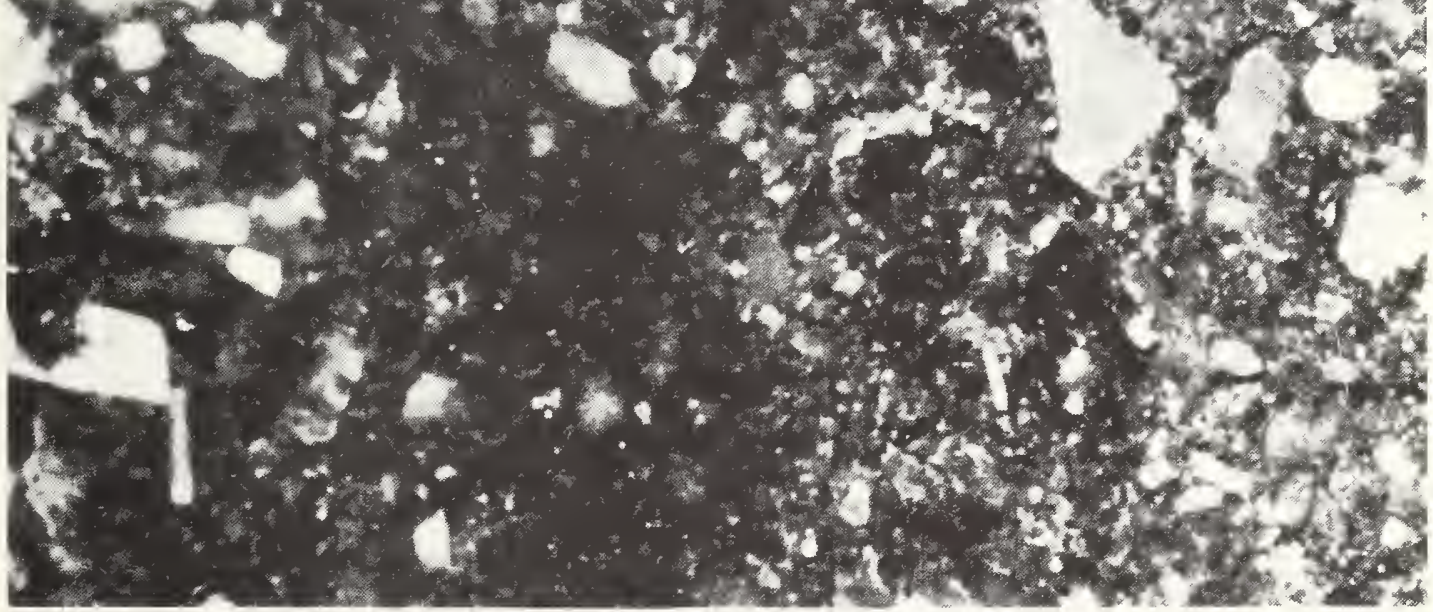

Figure 8. Epoxy-impregnated polished section of adobe from Tumacacori showing the distribution of aggregate in the fine matrix. lox magnification. 


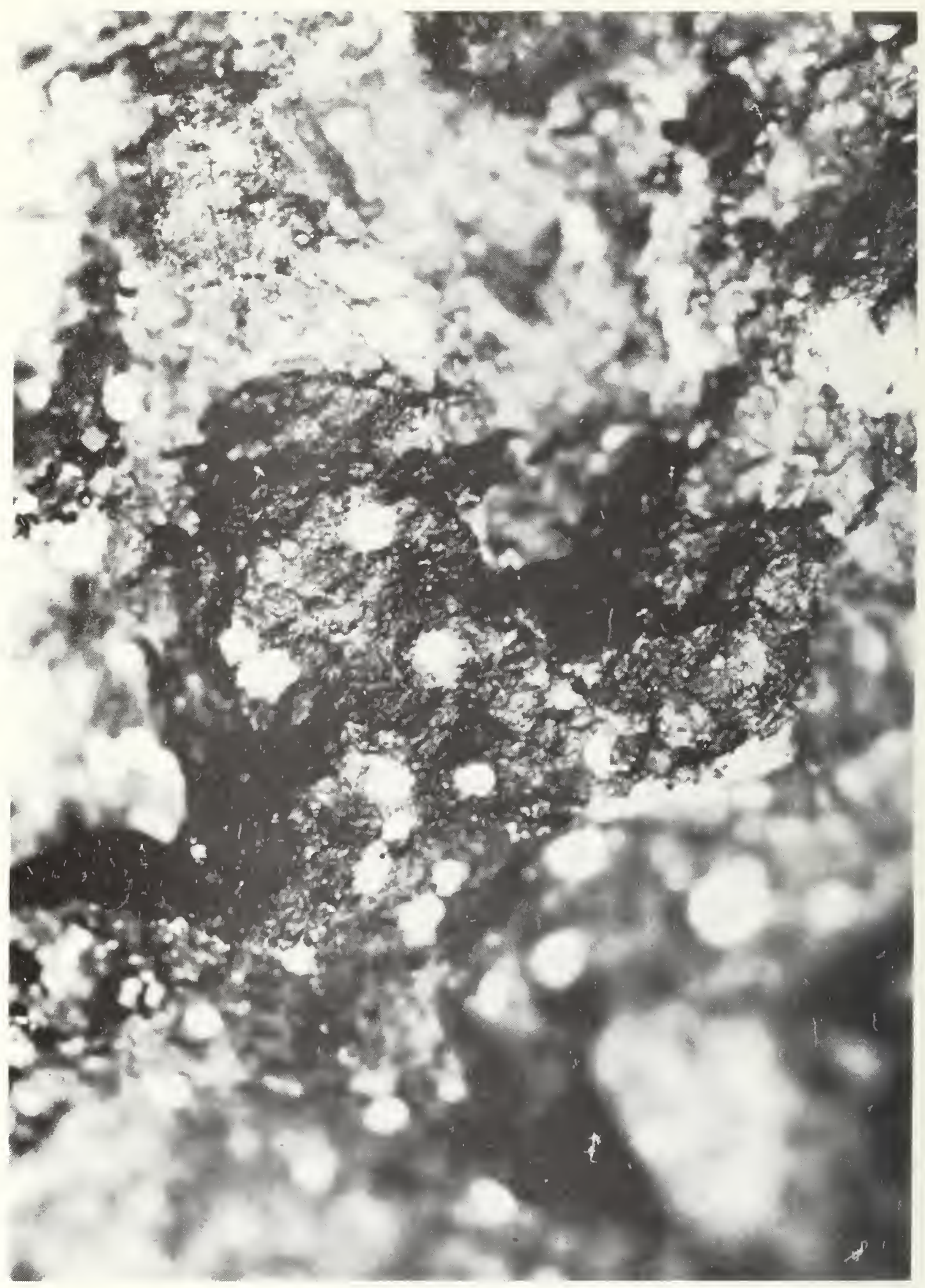

Figure 9. Epoxy-impregnated fracture surface of adobe from Tumacacori showing deposits of gypsum (white) filling the pores. 10X magnification. Sample $\mathrm{To}_{11}$. 


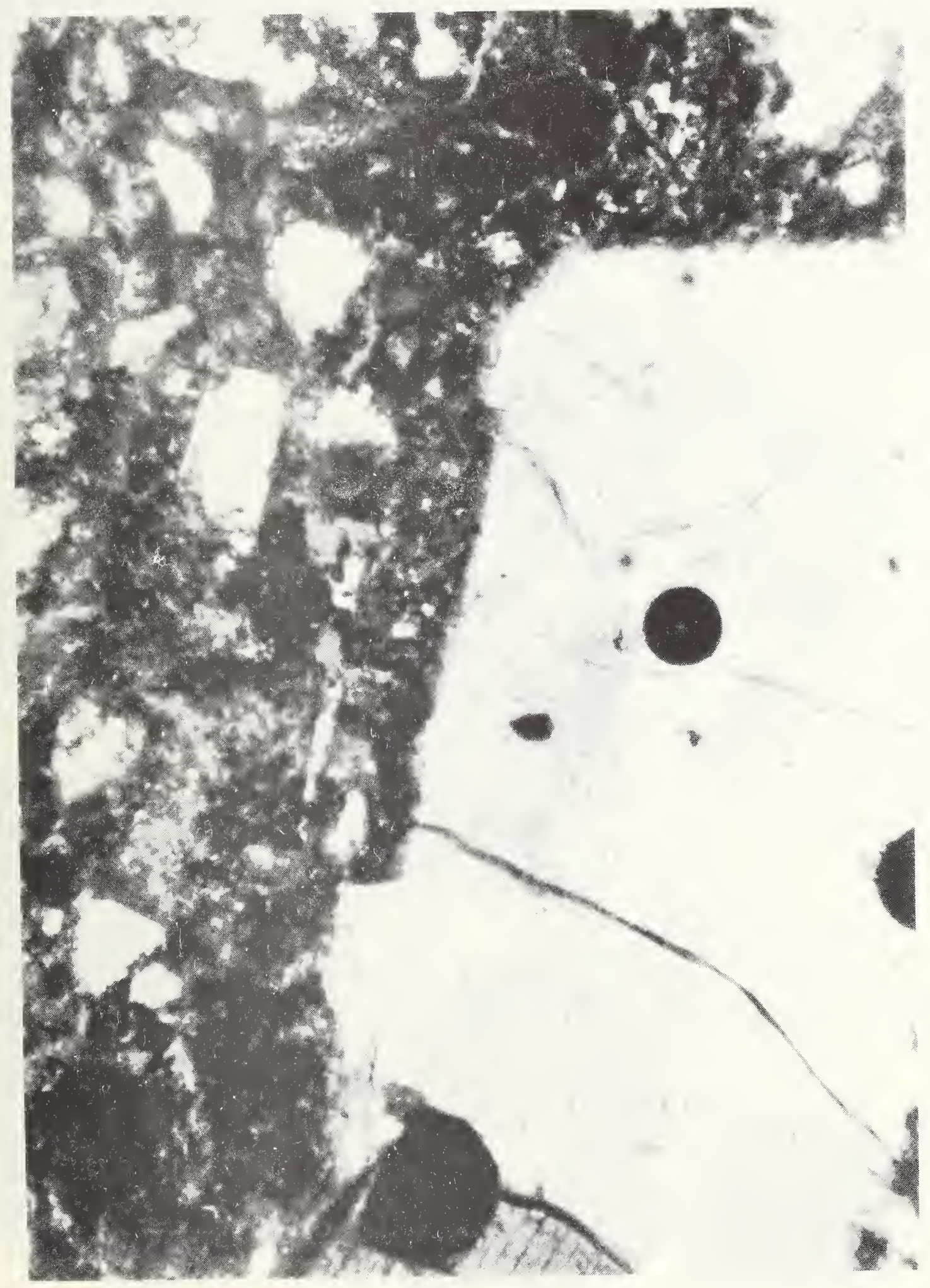

Figure 10. Thin section of adobe from Tumacacori showing a chemically zoned feldspar crystal in the silt-clay matrix. Such zoning is common in the detrital feldspars of this locality. Transmitted polarized light. l00X magnification. 


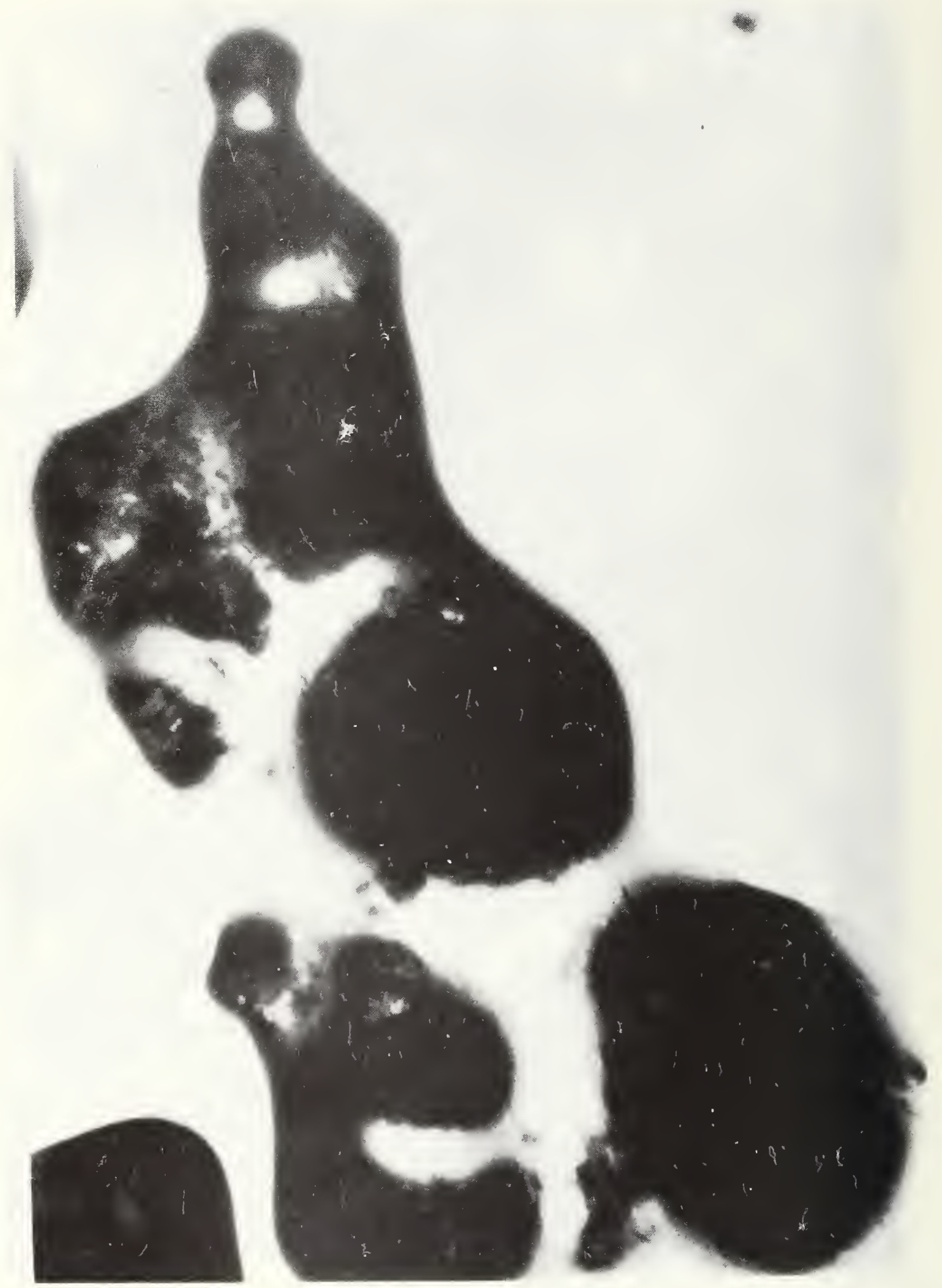

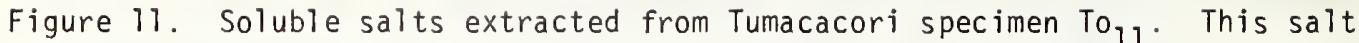
sample was dryed at $105^{\circ} \mathrm{C}$ to constant weight and then exposed to laboratory air $\left(23^{\circ} \mathrm{C}, 35 \% \mathrm{r.h}\right.$.) for 30 minutes. $65 \mathrm{X}$ magnification. Transmitted polarized light. 


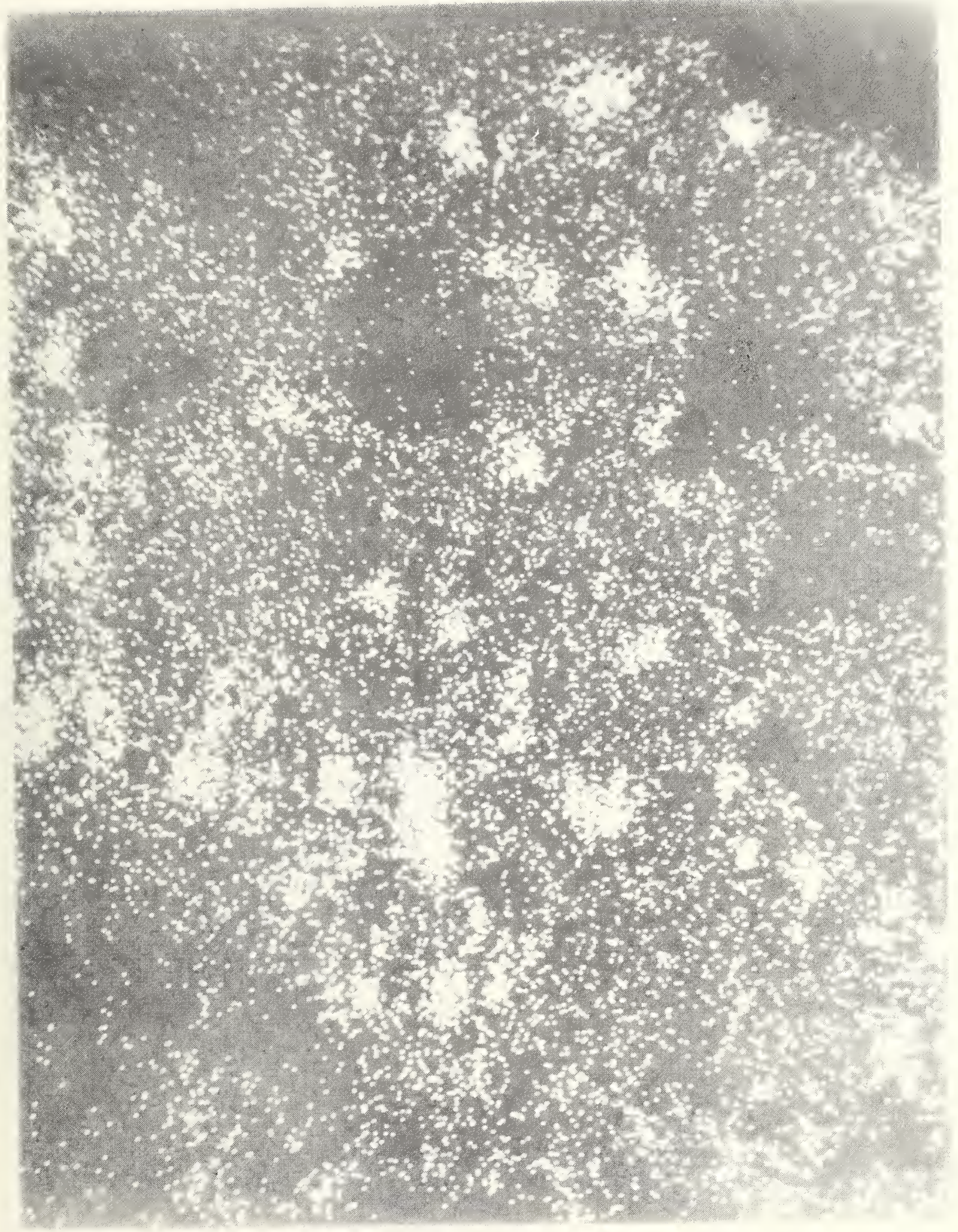

Figure 12. An energy dispersive x-ray map of the calcium and sulfur distribution in Tumacacori specimen To $17^{\circ}$ This shows the distribution of the gypsum particles (white areas) in this specimen. lox magnification. 


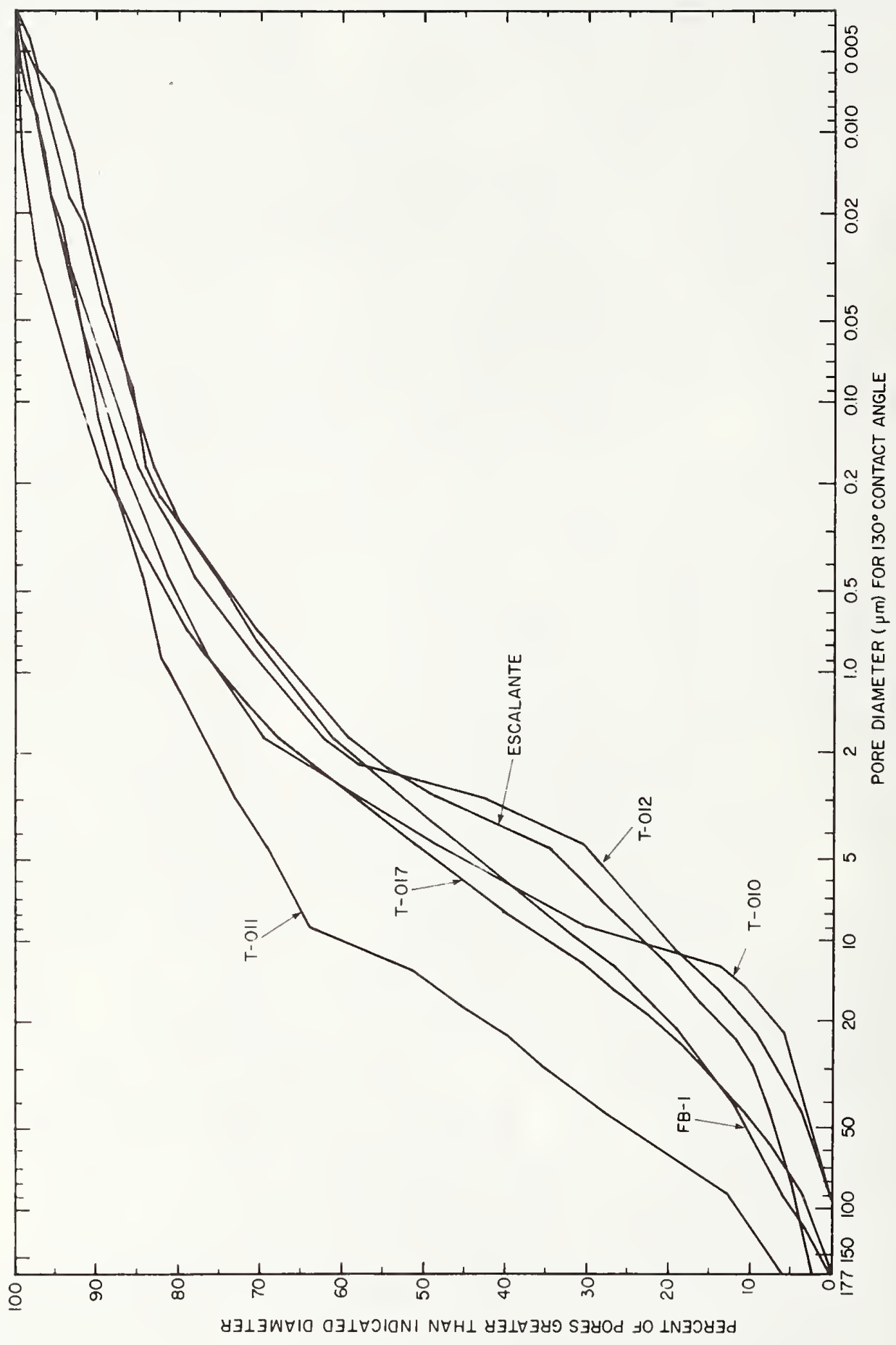

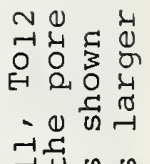

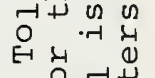
- $\begin{gathered}0.14 \\ -70\end{gathered}$ 엉 웜 स 1 -

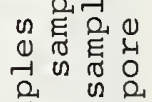
宥 क iी न त्रें 남 तै

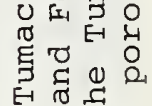
से . पा है ᄃ 。 - $0 \mathrm{~m}$

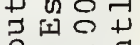
ने $\dot{0}$. प्र 品 चु ज्ञात 入 .

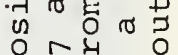
प्र० Q $E$ थ Е

$\dot{m}$

岂 

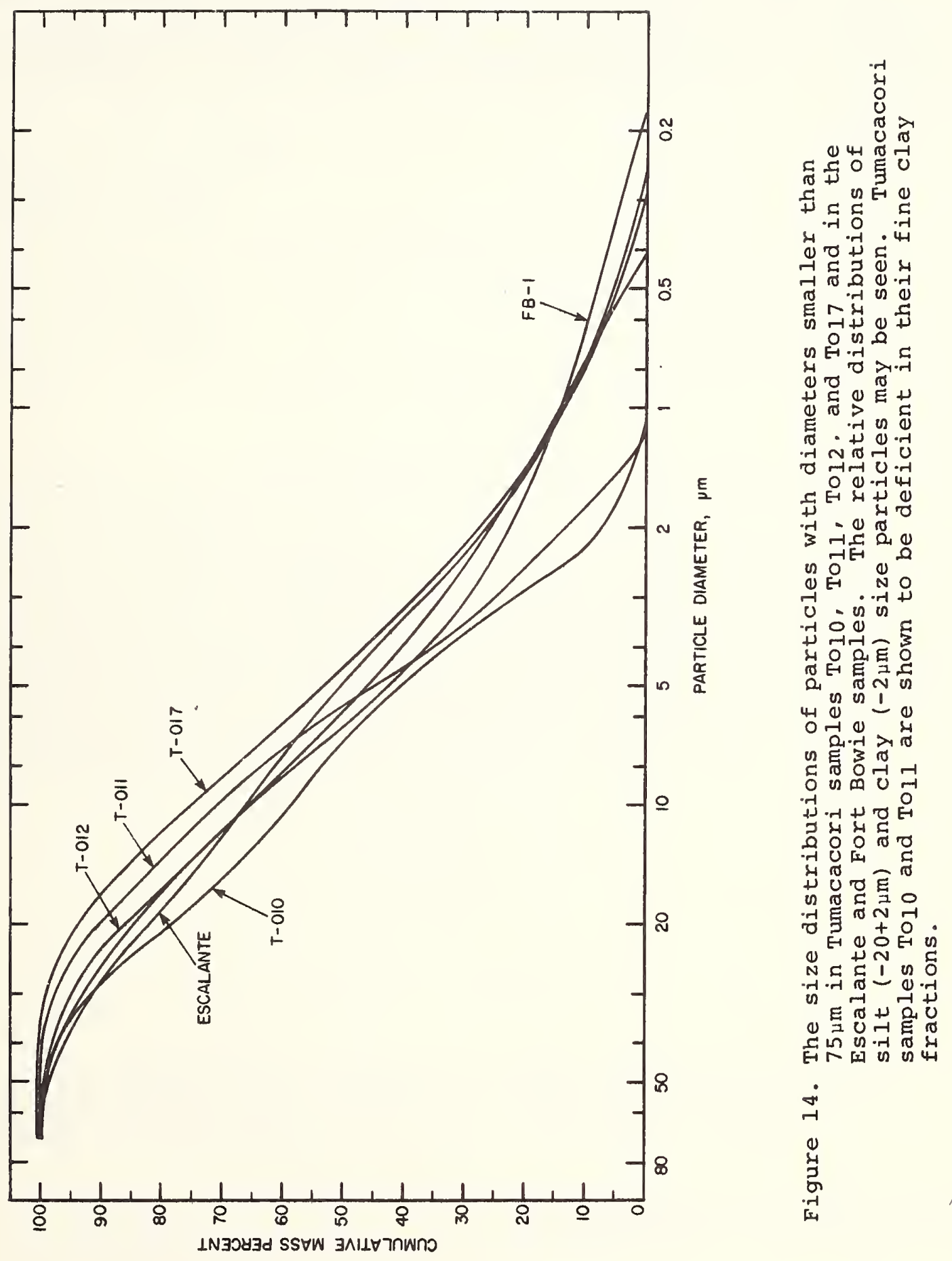
8. ACKNOWLEDGMENT

The authors wish to acknowledge the financial support of the Western Archeological Center of the National Park Service. In particular they wish to express their sincere thanks to George Cattanach, Dennis Fenn and Anthony Crosby of the National Park Service for their technical and administrative assistance. 
NBS.114A (REV. 7-73)

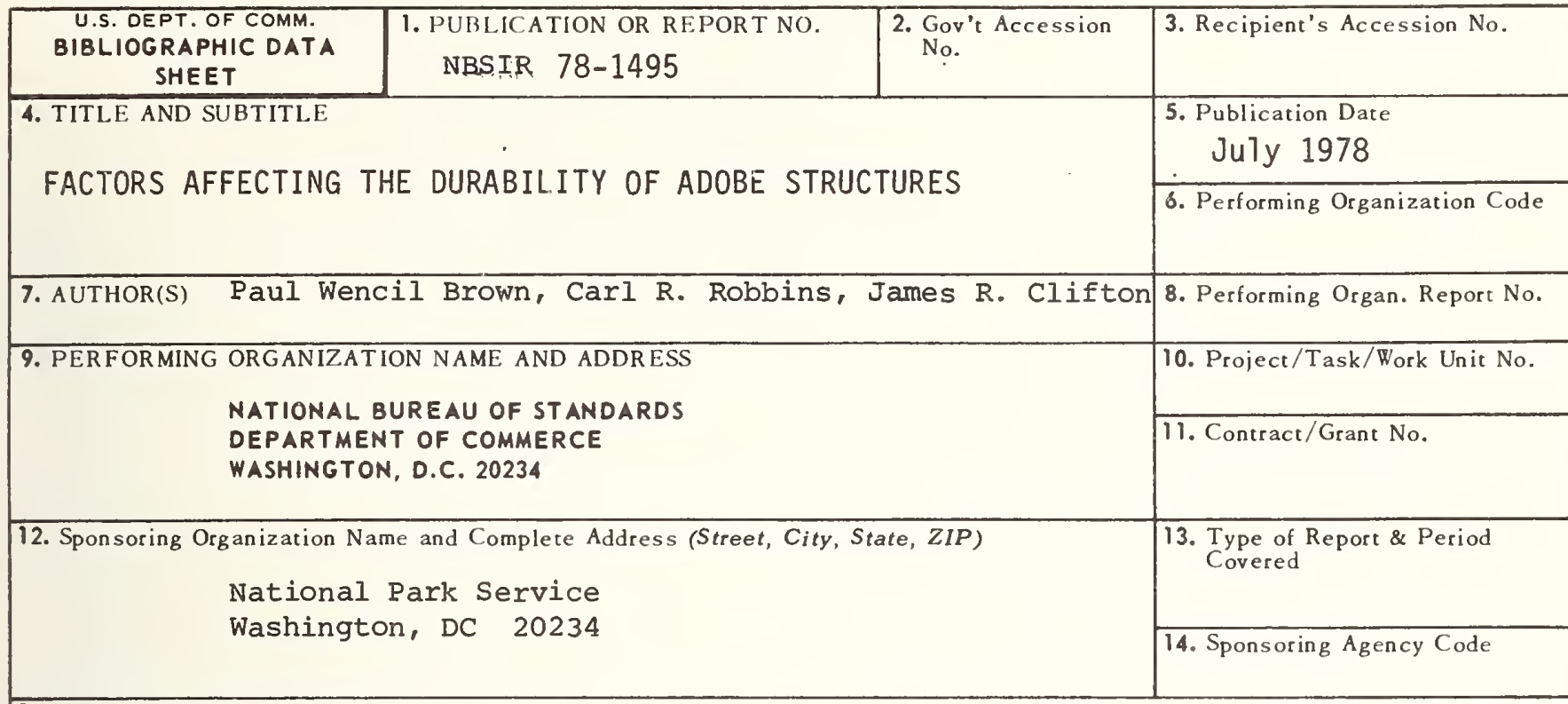

15. SUPPLEMENTARY NOTES

16. ABSTRACT (A 200-word or less factual summary of most significant information. If document includes a significant bibliography or literature survey, mention it here.)

Adobe samples from three sites of historic interest in the state of Arizona were analyzed to determine their mineral assemblages, particle size distributions, soluble salt contents, and porosities. These analyses were accompanied by microscopic observations of polished sections and thin sections. These data were correlated with the weathering observed and it was found that soluble salt action was responsible for the deterioration of the adobe from one of the sites. The nature of the particle size distribution has resulted in the rapid deterioration of the adobe from a second site. The adobe from a third site was found to be well consolidated due to the presence of large amounts of calcite.

\% KEY WORDS (six to twelve entries; alphabetical order; capitalize only the first letter of the first key word unless a proper name; separated by semicolons)

Adobe; clay; particle size distribution; soluble salt analysis; weathering; $\mathrm{x}$-ray analysis.

18. AVAILABILITY

For Official Distribution. Do Not Release to NTIS

Order From Sup. of Doc., U.S. Government Printing Office Washington, D.C. 20402, SD Cat. No. C13

[x] Order From National Technical Information Service (NTIS) Springfield, Virginia 22151

\begin{tabular}{|l|c|}
\hline $\begin{array}{l}\text { 19. SECURITY CLASS } \\
\text { (THIS REPURT) }\end{array}$ & $\begin{array}{c}\text { 21. NO. OF PAGES } \\
\text { UNCL RSSIFIED }\end{array}$ \\
\hline $\begin{array}{l}\text { 20. SECURITY CLASS } \\
\text { (THIS PAGE) } \\
\text { UNCLASSIFIED }\end{array}$ & 22. Price \\
$\$ 4.50$ \\
\hline
\end{tabular}



$\frac{2}{j}$

0

0

it

IF

-

$0 i$

\section{.}

